\title{
Oxidation Kinetics by Water Vapor of Nuclear Graphite Grade 2114
}

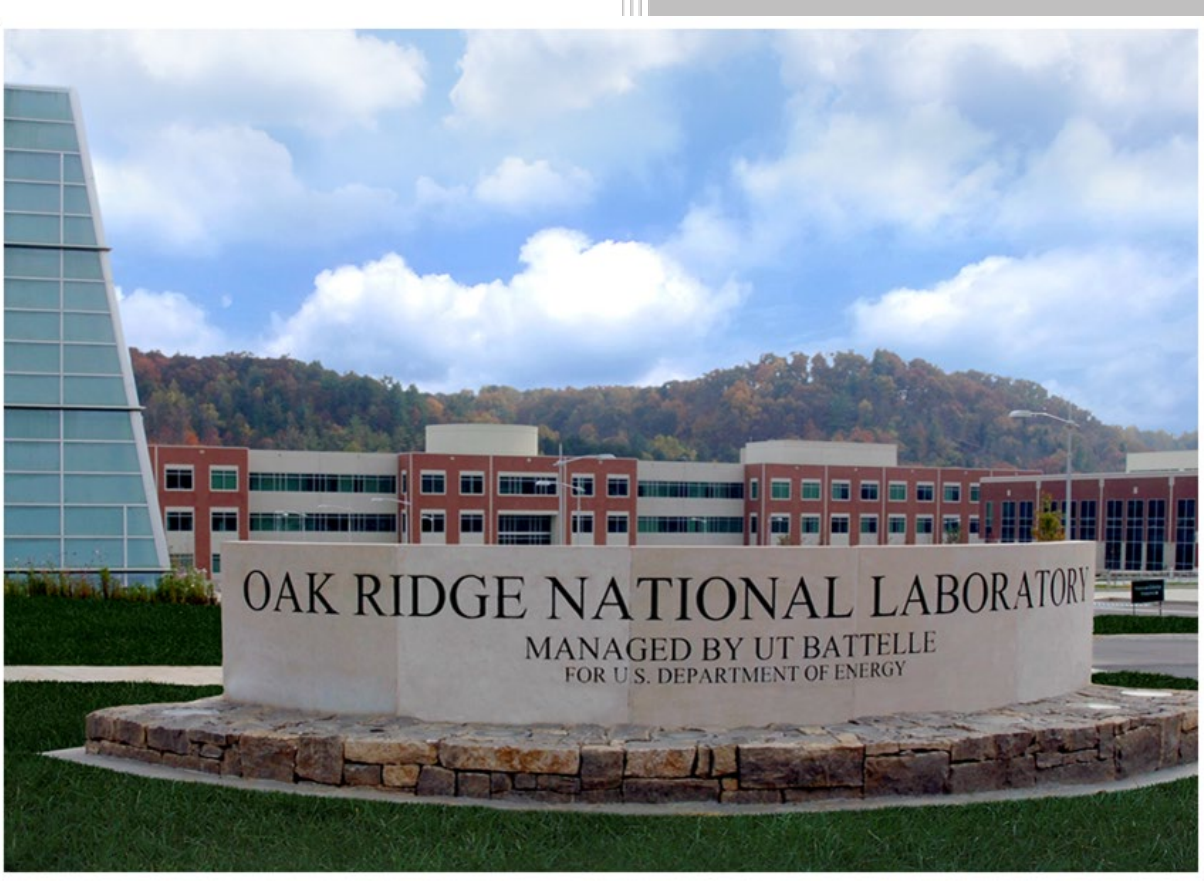

Approved for public release.

Distribution is unlimited.

Cristian Contescu

Yoonjo (Jo Jo) Lee

Robert Mee

November 2018 


\section{DOCUMENT AVAILABILITY}

Reports produced after January 1, 1996, are generally available free via US Department of Energy (DOE) SciTech Connect.

Website www.osti.gov

Reports produced before January 1, 1996, may be purchased by members of the public from the following source:

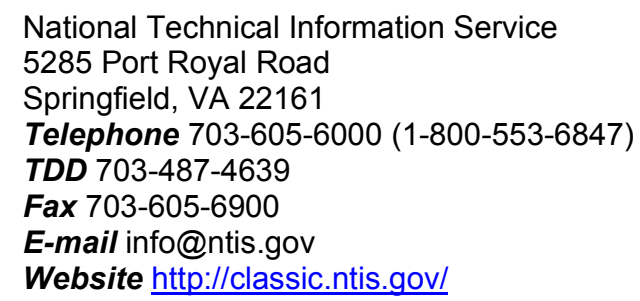

Reports are available to DOE employees, DOE contractors, Energy Technology Data Exchange representatives, and International Nuclear Information System representatives from the following source:

Office of Scientific and Technical Information

PO Box 62

Oak Ridge, TN 37831

Telephone 865-576-8401

Fax 865-576-5728

E-mail reports@osti.gov

Website http://www.osti.gov/contact.html

This report was prepared as an account of work sponsored by an agency of the United States Government. Neither the United States Government nor any agency thereof, nor any of their employees, makes any warranty, express or implied, or assumes any legal liability or responsibility for the accuracy, completeness, or usefulness of any information, apparatus, product, or process disclosed, or represents that its use would not infringe privately owned rights. Reference herein to any specific commercial product, process, or service by trade name, trademark, manufacturer, or otherwise, does not necessarily constitute or imply its endorsement, recommendation, or favoring by the United States Government or any agency thereof. The views and opinions of authors expressed herein do not necessarily state or reflect those of the United States Government or any agency thereof. 
Materials Science and Technology Division

\title{
OXIDATION KINETICS BY WATER VAPORS OF NUCLEAR GRAPHITE GRADE 2114
}

\author{
Cristian Contescu, ${ }^{1}$ Yoonjo (Jo Jo) Lee, ${ }^{1}$ and Robert Mee ${ }^{2}$ \\ ${ }^{1}$ Oak Ridge National Laboratory \\ ${ }^{2}$ University of Tennessee, Knoxville
}

November 2018

\author{
Prepared by \\ OAK RIDGE NATIONAL LABORATORY \\ Oak Ridge, TN 37831-6283 \\ managed by \\ UT-BATTELLE, LLC \\ for the \\ US DEPARTMENT OF ENERGY \\ under contract DE-AC05-00OR22725
}


This page was intentionally left blank 


\section{CONTENTS}

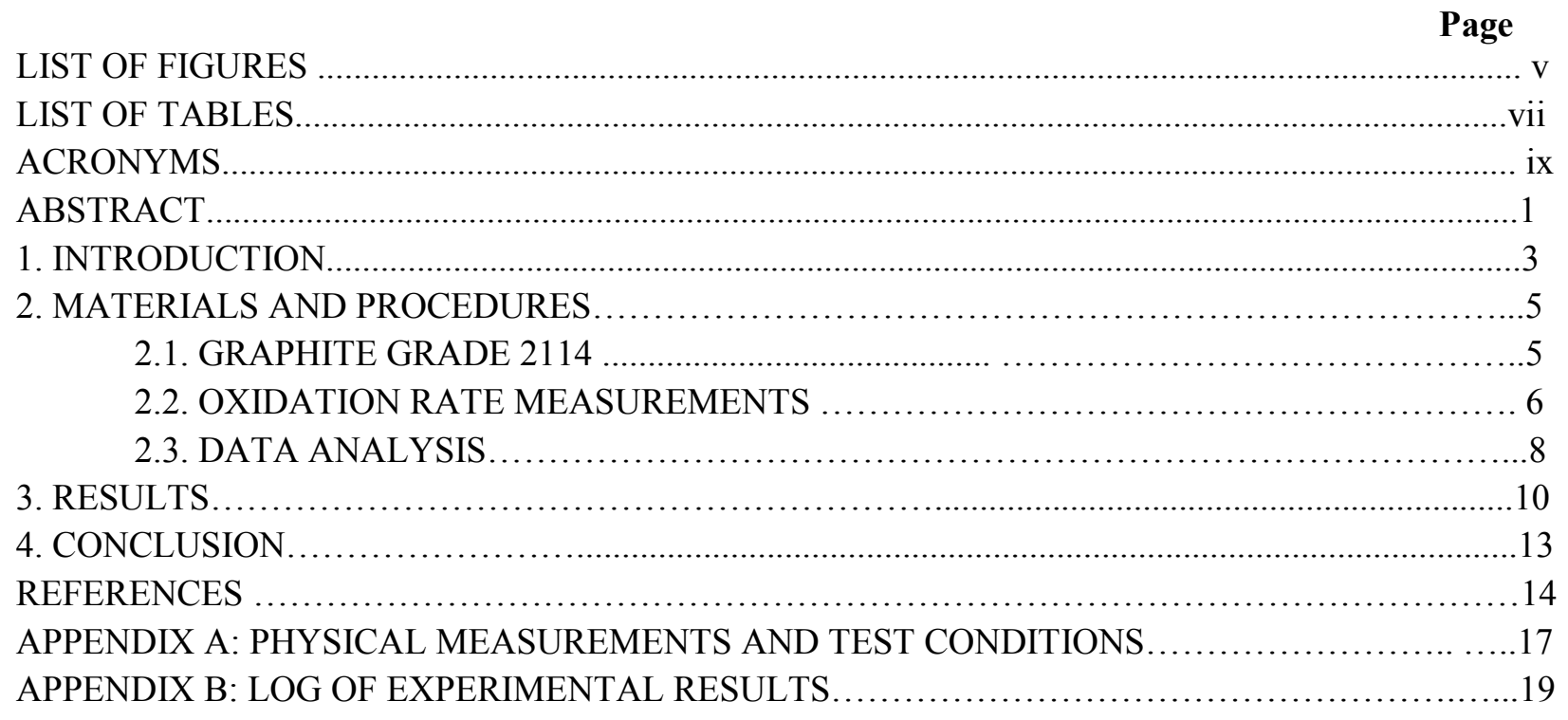


This page was intentionally left blank 


\section{LIST OF FIGURES}

Figure

Page

1. Optical microscopy image of graphite 2114 (polarized light) ..............................

2. Schematic showing the cutting diagram for oxidation specimens.......................... 6

3. Schematic of the experimental setup used for graphite oxidation measurements............. 7

4. Four views of the thermogravimetric apparatus and auxiliary gas lines and instruments.........8

5. Experimental oxidation rates at $P_{H_{2}}=0$ and trends predicted by two kinetic models ........... 11

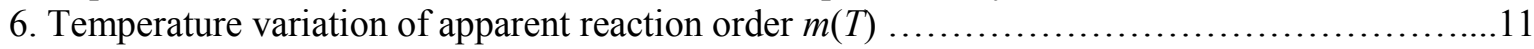

7. Measured and predicted oxidation rates using the classical LH and the new BLH model .......12 
This page was intentionally left blank 


\section{ACRONYMS}

ASTM American Society for Testing and Materials

BLH

Boltzmann-Langmuir-Hinshelwood (kinetic model)

GA

General Atomics (company)

HTGR

High Temperature Gas-cooled Reactor

LH

Langmuir-Hinshelwood (kinetic model)

ORNL

Oak Ridge National Laboratory

SSE

sum of squared errors

TAG

TPD

Thermo-analyseur gravimmetrique / gravimetric thermoanalyzer (instrument)

TPO temperature-programmed desorption

temperature-programmed oxidation

VHTR Very High Temperature Reactor 
This page was intentionally left blank 


\begin{abstract}
This report presents measurement results of oxidation rates by water vapor of nuclear graphite grade 2114 manufactured by Mersen, USA. This report completes kinetic study of chronic oxidation of grade 2114, of which partial data were compiled as a Letter Report in July 2017. The research is part of a broader program at Oak Ridge National Laboratory (ORNL) aiming at development of a comprehensive model for chronic oxidation of nuclear graphite in conditions relevant to operation of gas-cooled high-temperature reactors (HTGR). Grade 2114 is the fourth nuclear graphite investigated under this program. Experimental data measured at ORNL were analyzed in collaboration with Dr. Robert Mee (University of Tennessee, Knoxville) and graphite-specific parameters in the oxidation rate equation were determined. It was shown, once again, that the new Boltzmann-enhanced Langmuir-Hinshelwood (BLH) model recently proposed by ORNL is a better choice than the classical Langmuir-Hinshelwood (LH) model for prediction of chronic oxidation of graphite components during normal operation of HTGRs.
\end{abstract}


This page was intentionally left blank 


\section{INTRODUCTION}

Graphite is used as a moderator and structural material in high temperature gas-cooled reactors (HTGR). Although stable in reducing environments, graphite is susceptible to oxidation by traces of oxygen, water, and carbon dioxide that might be present in the helium coolant at the operating temperatures (about $700-950^{\circ} \mathrm{C}$ ). Even though the coolant chemical composition is strictly controlled, water (moisture) is the most difficult gas species to remove. Depending on specific HTGR design, the water vapor partial pressure may vary from about $5 \mathrm{~Pa}$ (Fort St. Vrain, USA, 1976-1979) to 0.2 Pa (Dragon, UK, 1964-1975), with most common values grouped around 1.1 - 1.4 Pa (Peach Bottom, USA, 1967-1974; HTTR, Japan, 1999; HTR-10 China, 2003; and HTR-PM project, China) at total helium pressures of 4 - $9 \mathrm{MPa}$ [1-6]. Over several decades of lifetime, it is inevitable that extremely slow, but continuous (chronic) oxidation of graphite will occur at high temperatures. The reaction products for oxidation by water are hydrogen and carbon monoxide. Their presence in the gas phase in contact with the graphite (or in graphite's pores) can shift the equilibrium and slow down the reaction rate:

$$
\mathrm{C}_{\text {graphite }}+\mathrm{H}_{2} \mathrm{O}_{\text {vapor }}=\mathrm{CO}_{\text {gas }}+\mathrm{H}_{2} \text { gas }
$$

This chronic graphite gasification may slowly but surely corrode the fuel elements and other structural components in the core, weakening their mechanical strength and potentially jeopardizing the reactor integrity. Early analysis of chronic oxidation effects was performed at General Atomics (GA) in the 1970's based on accelerated oxidation tests of graphite grade H-451, which at the time was the U. S. graphite candidate for gas-cooled reactors [7]. H-451 is medium fine-grain size $(1.25 \mathrm{~mm})$ extruded graphite manufactured from a petroleum precursor by Great Lakes Carbon in United States. ${ }^{1}$ The GA report [8] contains carefully measured oxidation rates in helium with controlled amounts of moisture and hydrogen. By fitting the observations to the kinetic model proposed by Langmuir, Hinshelwood and others (LH) [8] the authors provided numerical values of three kinetic constants and their temperature variation. Building on these results, Richards [9] analyzed water transport in porous graphite and its depletion by the oxidation reaction. He concluded that corrosion by moisture will affect only a thin layer (about 1-2 $\mathrm{mm}$ ) at the surface of graphite components, provided the steam concentration in the HTGR coolant is kept below $0.1 \mathrm{ppm}$ at a total design pressure of $63 \mathrm{~atm}$ (less than 6.4 Pa partial pressure) [9]. This prediction was cross-validated against unpublished density measurements made in Germany on graphite grade 2020 oxidized by water. The latter is fine grain $(0.015 \mathrm{~mm})$ graphite with completely different microstructure than the medium grain H-451.

The raw material used for fabrication of graphite $\mathrm{H}-451$ is no longer available. With the resurgence of interest in large and modular HTGR systems, new graphite grades are now considered for potential use. They have different precursors, fabrication techniques, and various structures with either small or medium grain sizes. It is well known by now that graphite microstructure has a strong effect on oxidation behavior [10-13]. Yet, for lack of information on oxidation behavior of the new graphite grades, reactor design and

\footnotetext{
${ }^{1}$ This report uses the latest classification of nuclear graphite grades based on their grain size (ASTM D8075-16, "Standard guide for Categorization of microstructural and microtextural features observed in optical micrographs of graphite").
} 
HTGR safety analysis continues to use the LH kinetic model with the parameters [7] specific to graphite H-451 [14-19]. Based on the current knowledge on graphite properties there are strong reasons to question whether extrapolating oxidation behavior of one graphite grade to another grade, with different origin and physical properties, and then using that as the design basis for reactor safety qualification, is the right thing to do. The stricter requirements of regulatory bodies demand that safety analysis is based on actual properties of each material loaded in the reactor. There is a strong need for proper characterization of chronic oxidation behavior of new grades of nuclear graphite proposed as candidates for HTGR and the very high temperature reactor (VHTR).

Investigation of nuclear graphite chronic oxidation by moisture was initiated at Oak Ridge National Laboratory in 2012. A large amount of experimental data was collected in the past few years on oxidation kinetics of medium fine-grained graphite (PCEA and NBG-17) and one superfine-graded graphite (IG-110). This work continued with the study of a second fine grain graphite (2114). Partial results from this study were presented in electronic letter report form to Idaho National Laboratory in July 2017 [20]. It was shown again that a new kinetic model [21,22] proposed first in 2016 is better suited than the classical LH model for representation of oxidation rates by moisture measured at very different conditions. The new Boltzmann-enhanced Langmuir-Hinshelwood (BLH) rate equation is a semi-global kinetic model [23] derived from the classical LH equation but enhanced with a temperature-dependent reaction order described by a Boltzmann distribution [22]. 


\section{MATERIALS AND PROCEDURE}

\subsection{GRAPHITE GRADE 2114}

Graphite 2114 is superfine grained isotropic graphite manufactured by isostatic molding by Mersen, USA (former Carbonne Lorraine). It is considered a possible candidate for use in HTGRs. According to manufacturer's specification [24], this graphite has an average grain size of $13 \mu \mathrm{m}$, low porosity (10\%), cumulative pore volume of only $7 \mathrm{~mm}^{3} / \mathrm{g}$, and the majority of pores with sizes lower than $1 \mu \mathrm{m}$. Figure 1 shows an optical microscopy mosaic image of this material recorded with polarized light. The image size is $1 \mathrm{~mm} \times 1 \mathrm{~mm}$.

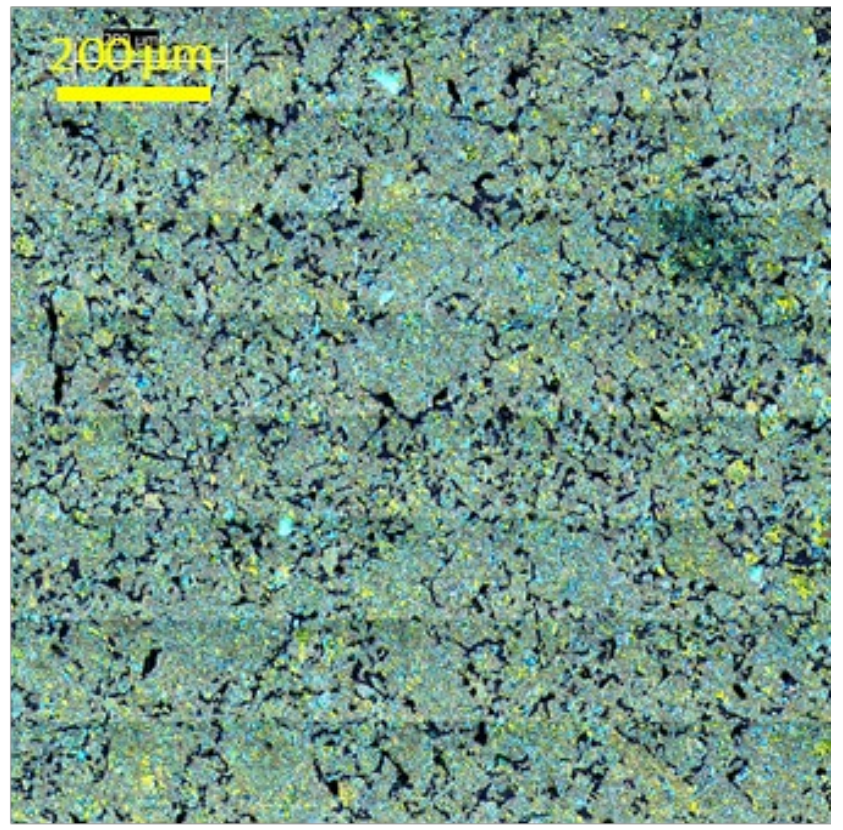

Figure 1: $\quad$ Optical microscopy image of graphite 2114 (polarized light)

Graphite specimens for oxidation studies were machined from two square bars cut from billet 101103 of grade 2114 acquired from Mersen. The cutting scheme is shown in Figure 2. A subsection of bar 2 (labeled sub-bar 2A) was used for machining of thin graphite slabs used for effective diffusivity measurements that will be reported in another document. The specimens used for oxidation studies were cylinders ( $25 \mathrm{~mm}$ length $\times 5 \mathrm{~mm}$ diameter). A hole $(0.75 \mathrm{~mm}$ diameter) near one end was used for suspension with a platinum wire in the thermogravimetric apparatus. 


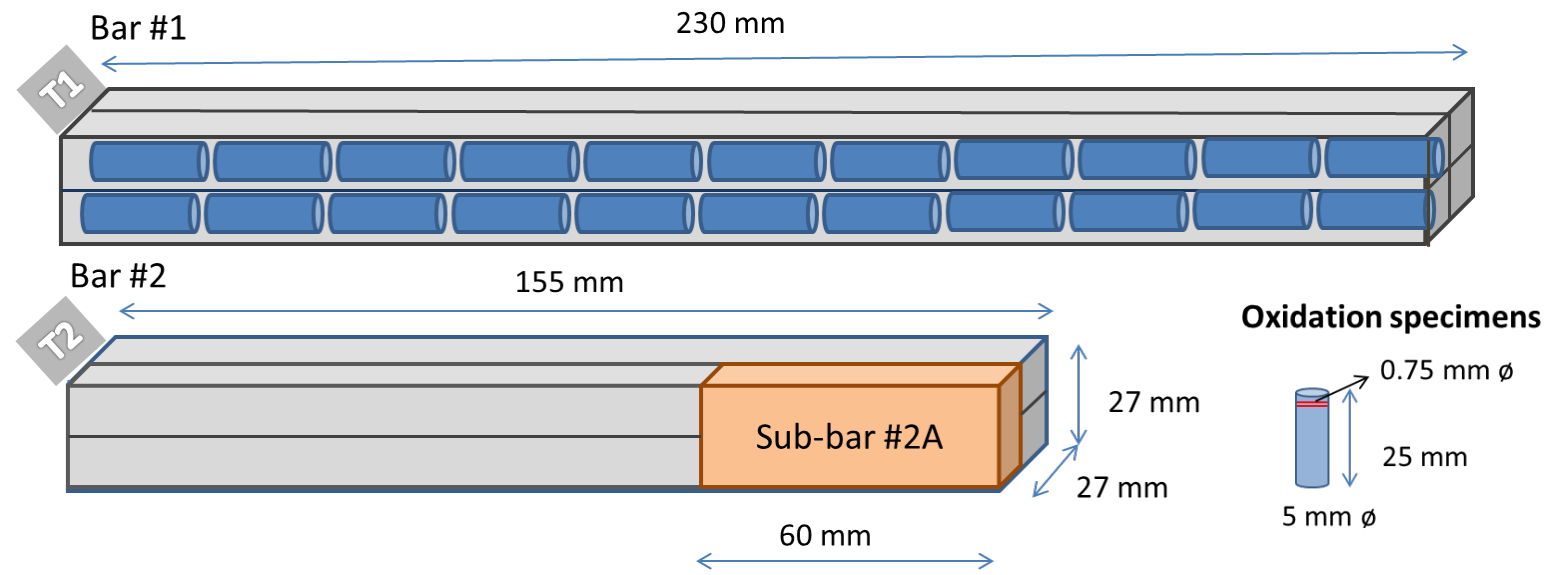

Figure 2: $\quad$ Schematic showing the cutting diagram for oxidation specimens. Sub-bar 2A was used for machining the graphite slabs used for water diffusivity measurements.

\subsection{OXIDATION RATE MEASUREMENTS}

Oxidation rates were measured in the dual symmetrical thermogravimetric analyzer TAG 16/18 (Setaram, France). This instrument has a resolution of $0.5 \mu \mathrm{g}$ and excellent temperature control. Details on the experimental setup can be found elsewhere [21,25-27]. In summary, graphite cylinders ( $25 \mathrm{~mm}$ long, 5 $\mathrm{mm}$ diameter) were oxidized at constant flow conditions $(1.5 \mathrm{~L} / \mathrm{min}$, atmospheric pressure $)$ using ultrahigh purity helium $\left(>99.999\right.$ vol. \%) containing controlled partial pressures of water vapor $\left(3<\mathrm{P}_{\mathrm{H} 2 \mathrm{O}}<1200 \mathrm{~Pa}\right)$ and hydrogen $\left(0<\mathrm{P}_{\mathrm{H} 2}<150 \mathrm{~Pa}\right)$. Oxidation rates were obtained from the weight loss during 3 hours of exposure at constant temperature (between 800 and $1100^{\circ} \mathrm{C}$ ) and were normalized to the actual weight of the specimens. Fresh specimens were used for every new set of gas composition $\left(P_{H 2 O}, P_{H 2}\right)$. With gas composition held fixed, the temperature was raised stepwise from the lowest to the highest in $50{ }^{\circ} \mathrm{C}$ increments. Each specimen was tested at as many of 7 temperatures. Gas compositions were adjusted by varying the flow rate ratios between a flow of dry He, a second flow of He humidified in a controlled temperature bubbler, and (occasionally) a third flow of dry $1 \% \mathrm{H}_{2}$ / balance He. Gas flow rates of each gas stream were measured by calibrated mass flow controllers which were adjusted and recorded by a LabView application. The same application controlled the water bath temperature and recorded barometric pressure in the laboratory. The moisture content of reunited gas flows was measured just before the inlet port of the thermogravimetric balance by a precision chilled mirror hygrometer. Figure 3 shows a schematic of the experimental setup. The final weight loss for each specimen was not higher than $1 \%$. It was assumed that oxidation was in the chemical control regime and the rates measured were essentially not affected by diffusion. All gases were ultrahigh purity grade and the water for steam generation was ultra-high purity plasma-grade. The hydrogen concentration in the $\mathrm{H}_{2} / \mathrm{He}$ mixture was certified by the gas mixture provider (AirGas) and the concentration of $\mathrm{H}_{2}$ in the oxidation chamber was calculated from the flow rate values.

Physical measurements data for the 47 graphite specimens used in this study, along with the test conditions employed, are provided in Appendix A. 


\section{Setup for graphite oxidation in $\mathrm{H}_{2} \mathrm{O}$-He mixtures}

\begin{tabular}{l} 
Conditions: \\
Temperature: $800 \ldots 1100^{\circ} \mathrm{C}$ \\
$P_{\text {roo }}=3 \ldots 1200 \mathrm{~Pa}$ \\
$P_{r 2}=0 \ldots 150 \mathrm{~Pa}$ \\
Total flow rate $1.5 \mathrm{~L} / \mathrm{min}$ (balance $\mathrm{He}$ ) \\
\hline
\end{tabular}

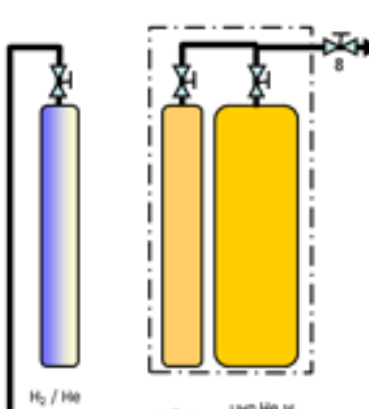

$16 / 100$ We He we He is
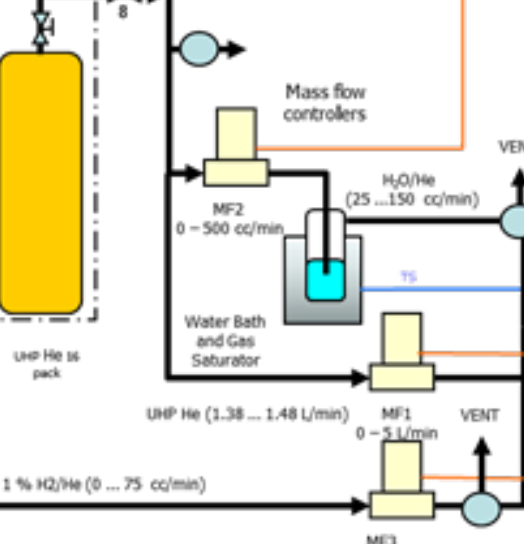

2003

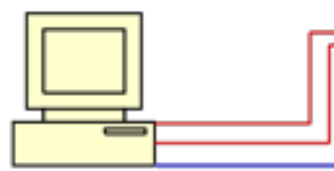

$0-250 \mathrm{co} / \mathrm{mm}$

PC computer

TS = temperature sensor $/$ controller

MF-1 ... MF.3 = mass flow controllers

Figure 3: Schematic of the experimental setup used for graphite oxidation measurements.

Figure 4 shows a general view of the equipment, details of the gas lines with the hygrometer and the water bath used for helium humidification, and two views of the TAG instrument with the dual furnace in the lowered position. The graphite specimen is attached to one arm of the microbalance (right side) and the other arm (left side) holds a reference quartz cylinder with the same volume as the graphite specimen. This symmetrical construction allows for fine compensation of gas buoyancy that always occurs in a flow system. Although temperature variations caused apparent weight variations in the system (related to gas density variations), in isothermal conditions the quartz reference maintains stable weight, allowing for accurate measurements of weight changes of the graphite samples. 

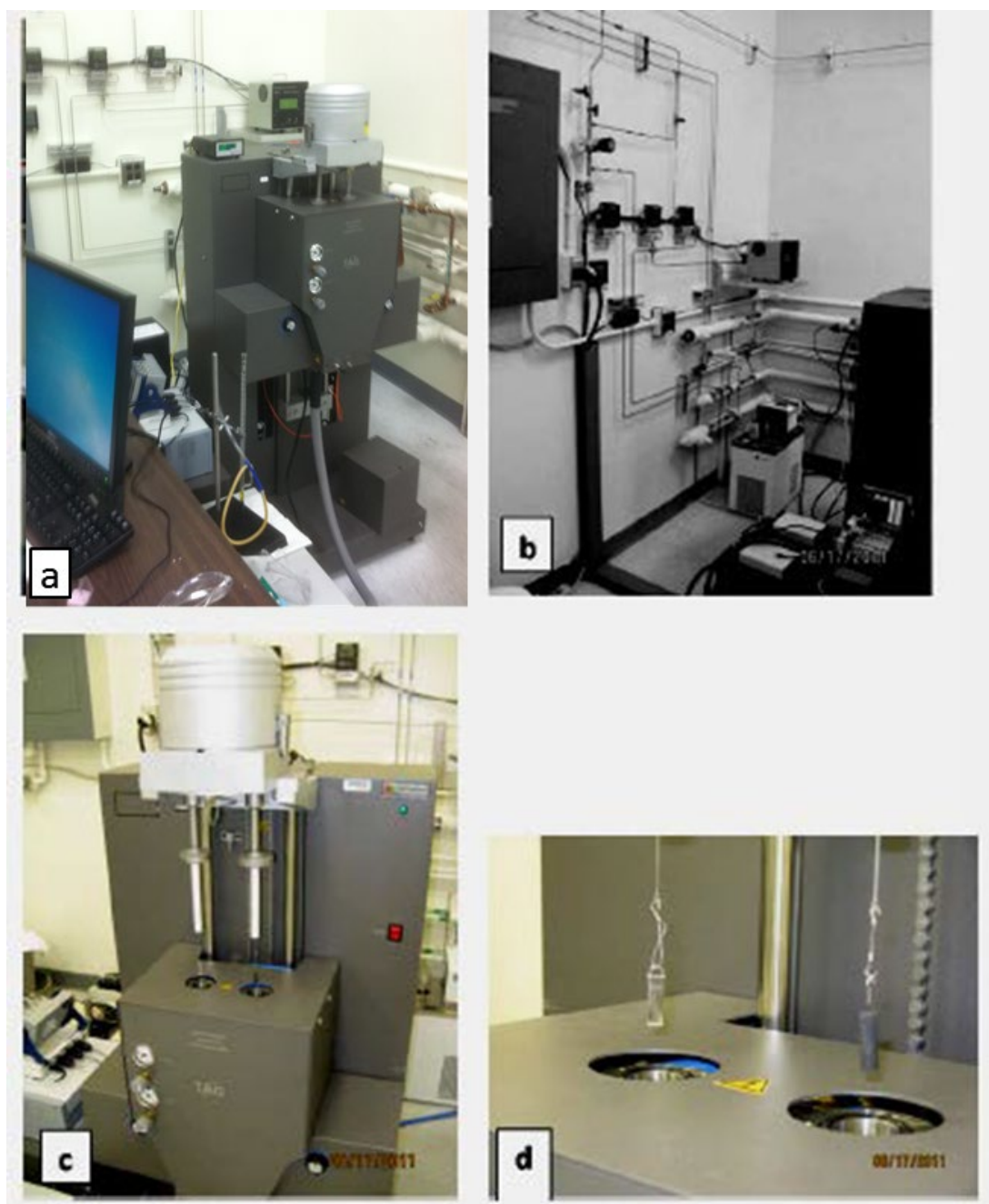

Figure 4: $\quad$ Four views of the thermogravimetric apparatus and auxiliary gas lines and instruments: (a) general view; (b) gas lines, water bath humidifier and hygrometer; (c) open furnace showing the two arms of the symmetrical balance; (d) graphite specimen (right) and quartz reference (left) attached to the high sensitivity microbalance through Pt wires and hanging rods

\subsection{DATA ANALYSIS}

Two hundred eighty-seven rate values were collected at various gas compositions and temperatures. A small number of observations were invalidated because of experimental errors, more frequently encountered for very low oxidation rates that were sometimes below the sensitivity limit of the equipment. All valid data were simultaneously analyzed by solving a set of multiple non-linear rate equations (to be introduced below) from which the most probable parameter values were found by minimization of the sum of squared errors (SSE) for $Y=\log$ (Rate) where $Y$ is the rate measured at any given condition. Two different rate equations were used for data analysis, as follows: 
- Classical Langmuir-Hinshelwood (LH) equation [7,8]:

$$
\begin{gathered}
\text { Rate }_{\mathrm{LH}}\left(P_{\mathrm{H} 2 \mathrm{O}}, P_{\mathrm{H} 2}, T\right)=\frac{k_{1} P_{\mathrm{H} 2 \mathrm{O}}}{1+k_{2}\left(P_{\mathrm{H} 2}\right)^{0.5}+k_{3} P_{\mathrm{H} 2 \mathrm{O}}} \\
\text { where } k_{i}=A_{i} \exp \left(-\frac{E_{i}}{R T}\right)
\end{gathered}
$$

In these equations Rate is weight-normalized oxidation rate $\left(\mathrm{mg}\right.$ oxidized $/ \mathrm{mg}$ initial $/ \mathrm{s}$, or $\left.\mathrm{s}^{-1}\right), T$ is the temperature $(\mathrm{K}), E$ is the activation energy $\left(\mathrm{J} \mathrm{mol}^{-1}\right)$, and $R$ is the gas constant $\left(8.314 \mathrm{~J} \mathrm{~mol}^{-1} \mathrm{~K}^{-1}\right)$. This kinetic model has six parameters which must be estimated by fitting all data: three preexponential factors $\left(A_{i}, i=1,2,3\right)$ and three apparent activation energies $\left(E_{i}, i=1,2,3\right)$.

- The Boltzmann-enhanced Langmuir-Hinshelwood model [21,22]:

$$
\begin{aligned}
& \text { Rate }_{B L H}\left(P_{H 2 O}, P_{H 2}, T\right)=\frac{k_{1}\left(P_{H 2 O}\right)^{m(T)}}{1+k_{2}\left(P_{H 2}\right)^{0.5}+k_{3}\left(P_{H 2 O}\right)^{m(T)}} \\
& \text { where } k_{i}=A_{i} \exp \left(-\frac{E_{i}}{R T}\right) \quad \text { and } \quad m(T)=m_{\max }+\frac{m_{\min -m_{\max }}}{1+\exp \left(\frac{T-T_{o}}{\theta}\right)}
\end{aligned}
$$

This new BLH kinetic model [21,22] accounts for faster increase of oxidation rates at high water vapor pressure $(>100 \mathrm{~Pa})$ and high temperatures $\left(>950^{\circ} \mathrm{C}\right)$ than what is predicted by the $\mathrm{LH}$ model. Differences between the experimental rates and those predicted by the LH model were also observed in prior studies on medium grain (PCEA, NBG-17) and superfine grain (IG-110) graphite in the same range of oxidant pressures and temperatures [22]. To represent all data by a unique, more robust model, a correction was introduced in the BLH model, by assuming that the reaction order for oxidant (water) depends on temperature, $m(T)$. This dependence, expressed by eq. (2a), was best modeled by the integral Boltzmann distribution function, with four new parameters: $m_{\min }$ and $m_{\max }$ that define the range of apparent reaction order, $T_{\mathrm{o}}$ which is a characteristic temperature associated with the inflection of $m(T)$ function, and $\theta$ which is a scaling parameter equal to the inverse slope of $m(T)$ at $T_{\mathrm{o}}$. With these changes, the BLH model has ten parameters that must be estimated from the collected data. 


\section{RESULTS}

The table in Appendix B contains all oxidation rate data and their corresponding experimental conditions. Figure 5 shows some of the experimental reaction rates (only those measured at $P_{\mathrm{H} 2}=0$ ) as a function of $P_{\mathrm{H} 2 \mathrm{O}}$ and temperature. These data (and those measured in mixtures containing $\mathrm{H}_{2} \mathrm{O}$ and $\mathrm{H}_{2}$ ) were fitted with the analytical expressions shown below, which were obtained by combining eqs. (1) and (1a), and respectively (2) and (2a):

$$
\begin{aligned}
\text { Rate }_{\mathrm{LH}}=\frac{a_{1} \exp \left(-\frac{E_{1}}{R T}\right)\left(P_{H 2 O}\right)}{1+A_{2} \exp \left(-\frac{E_{2}}{R T}\right)\left(P_{H 2}\right)^{0.5}+A_{3} \exp \left(-\frac{E_{3}}{R T}\right)\left(P_{H 2 O}\right)} \\
\text { Rate }_{\mathrm{BLH}} \frac{A_{1} \exp \left(\frac{-E_{1}}{R T}\right)\left(P_{H 2 O}\right)}{\left[m_{\max }-\frac{m_{\max }-m_{\min }}{\left.1+\exp \left(\frac{T-T_{O}}{\theta}\right)\right]}\right.} \\
1+A_{2} \exp \left(-\frac{E_{2}}{R T}\right)\left(P_{H 2}\right)^{0.5}+A_{3} \exp \left(-\frac{E_{3}}{R T}\right)\left(P_{H 2 O}\right)^{\left.m_{\max }-\frac{m_{\max }-m_{\min }}{1+\exp \left(\frac{T-T_{O}}{\theta}\right)}\right]}
\end{aligned}
$$

All parameters determined from best fit of the two models are listed in Table 1. The least squares analysis was based on minimization of the sum of squared errors for $\ln ($ Rate). The isothermal trends calculated with the best fitted parameters from these models are also plotted, at each temperature, in Figure 5. It is immediately seen that the LH model cannot reproduce fast oxidation rates at high water pressures $\left(P_{\mathrm{H} 2 \mathrm{O}}>100 \mathrm{~Pa}\right)$ and high temperatures $\left(T>950^{\circ} \mathrm{C}\right)$. Moreover, the trend predicted by the $\mathrm{LH}$ model is too conservative. According to this model, the oxidation rates would reach asymptotically a constant value when $P_{H 2 O}$ increases. That maximum rate would be dependent only on temperature (Fig. 5, top panel). In contrast, the experimental data show a different behavior, incompatible with the LH model for rates approaching the maximum rate. The oxidation rates continue to increase with $P_{\mathrm{H} 2 \mathrm{O}}$ and the rate of their variation (the slope on double logarithmic representations of Fig. 5) depends on temperature. This supports the hypothesis that the reaction order for water depends on temperature. The observed apparent reaction orders calculated from experimental data are plotted versus temperature in Figure 6. This sigmoidal dependence on temperature is accurately reproduced by the integral Boltzmann distribution function. The explicit expression of $m(T)$ is shown above, eq. (2a). In contrast, the LH model predicts for the same data just a slow linear variation with temperature, which evidently is not observed experimentally.

Table 1: $\quad$ Temperature variation of kinetic constants defined in Eqs. (1) and (2) for LH and BLH models, respectively

\begin{tabular}{|lll|}
\hline \multicolumn{1}{|c|}{ LH model } & \multicolumn{1}{c|}{ BLH model } \\
\hline \hline$k_{1}$ & $3.89 \mathrm{E}-07 \times \exp (-57800 / \mathrm{R} T)$ & $9.13 \mathrm{E}-12 \times \exp (61380 / \mathrm{R} T)$ \\
$k_{2}$ & $2.56 \mathrm{E}-02 \times \exp (23920 / \mathrm{R} T)$ & $1.47 \mathrm{E}+00 \times \exp (-1650 / \mathrm{R} T)$ \\
$k_{3}$ & $4.91 \mathrm{E}-09 \times \exp (167230 / \mathrm{R} T)$ & $3.38 \mathrm{E}-14 \times \exp (280600 / \mathrm{R} T)$ \\
$m(T)$ & & $1.463-1.400 /[1+\exp ((\mathrm{T}-1288) / 39.8)]$ \\
\hline
\end{tabular}



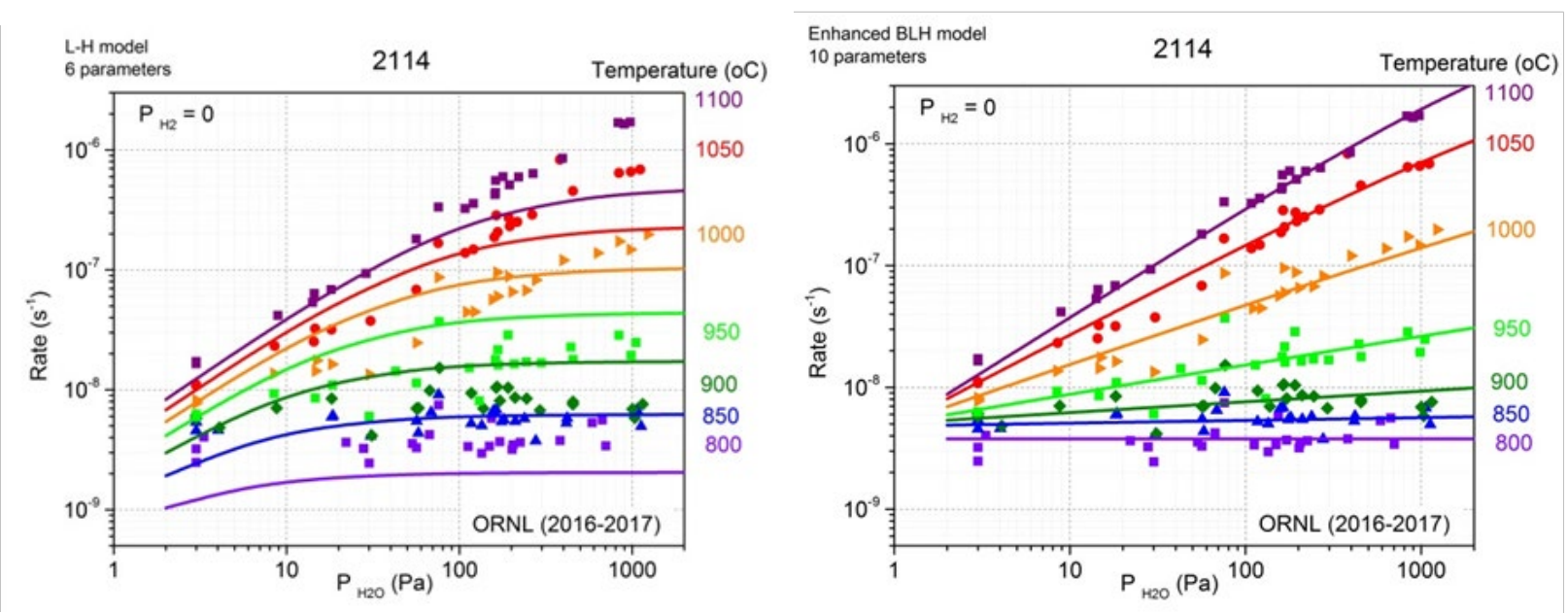

Figure 5: $\quad$ Experimental oxidation rates at $P_{\mathrm{H} 2}=0$ and trends predicted by two kinetic models: LH (left) and BLH (right)

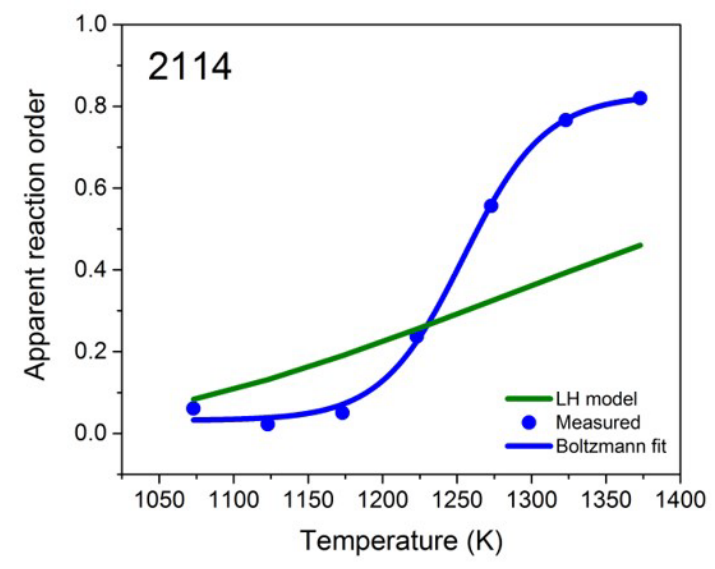

Figure 6: $\quad$ Temperature variation of apparent reaction order $m(T)$. Data based on observed oxidation rates are shown by symbols, along with their fit by the Boltzmann distribution function, eq. (2). The LH model predicts, for the same data, a linear dependence which is not observed experimentally.

Figure 7 compares the quality of fit afforded by the LH and BLH models. The double logarithmic plots show observed and predicted rate values in experiments with water only (blue symbols) and with water with hydrogen added (red symbols). The higher the correlation coefficient between observed and predicted rates, the better the fit. With the data available, the correlation coefficient calculated for the LH model is only $\mathrm{R}^{2}=0.79$, but it is $\mathrm{R}^{2}=0.91$ for the BLH model. The BLH model reproduces the measured rates better than the LH model and can therefore be used with greater confidence for prediction of oxidation rates. There is some data scattering in the range of low oxidation rates, especially in experiments with hydrogen added. The scattering is observed for both kinetic models, but it is larger for the LH model and smaller for the BLH model. 

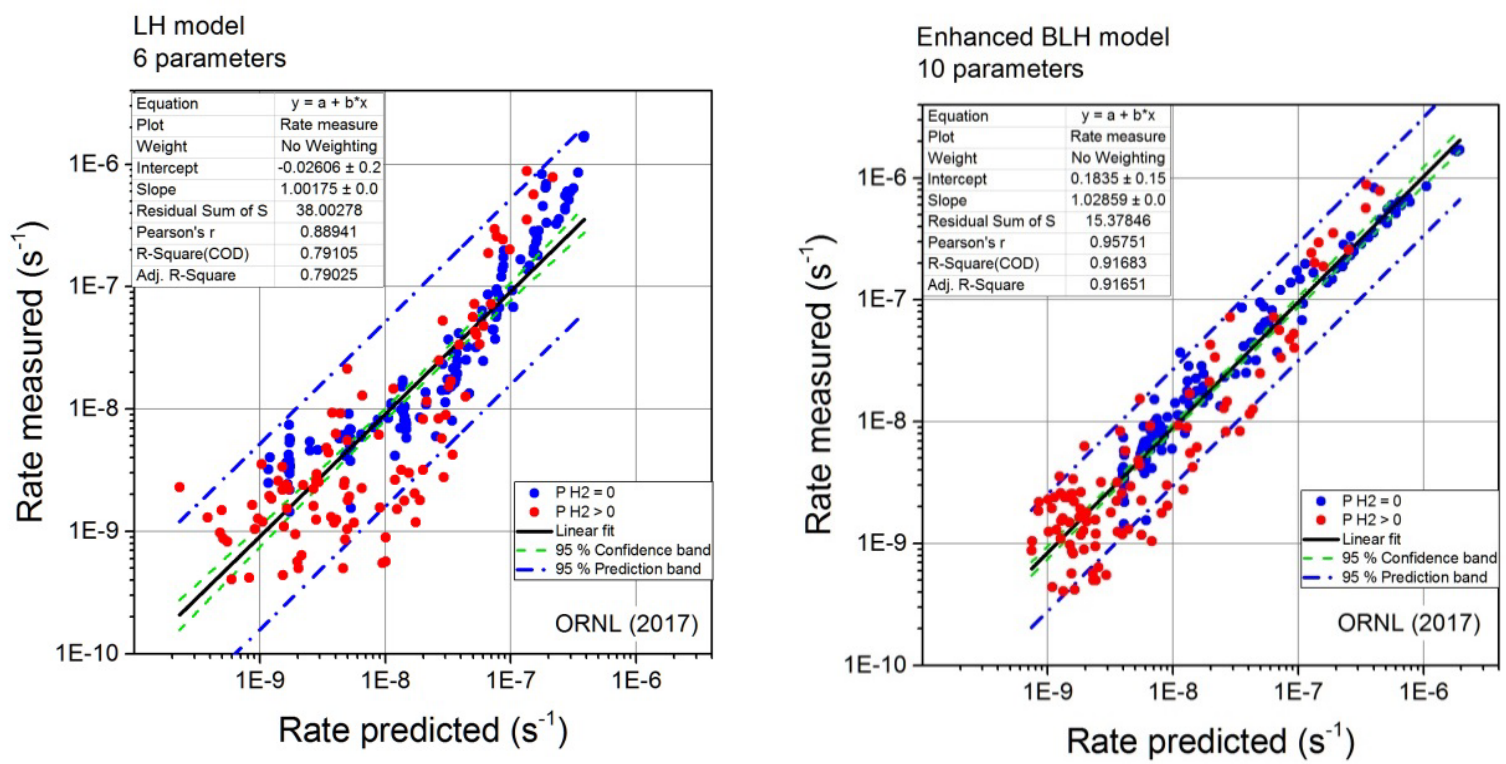

Figure 7: $\quad$ Measured and predicted oxidation rates using the classical LH model (left) and the new BLH model (right). Blue symbols are for oxidation by moisture only and red symbols for oxidation by moisture with added hydrogen. 


\section{CONCLUSION}

The work presented in this report is part of a larger program, aimed at characterization of chronic effects caused by oxidation by moisture of the new grades of graphite that can be potentially used in HTGRs. The results from current kinetic experiments with graphite 2114 adds new information to a series of similar results obtained for grades PCEA, NBG-17, and IG-110 in previous years [21,22]. This work is inevitably slow because oxidation by water is an extremely slow process. Kinetics is explored through a large number of accelerated oxidation tests, where measured rates are tens or hundreds of times faster than the expected rates under HTGR operating conditions. The underlying assumption of the study is that accurate characterization of effects of high water and hydrogen concentrations can be used to deduce the behavior at pressures too low for direct measurements. Variability of local properties in graphite and the experimental errors (enhanced in slow oxidation conditions) require that data analysis is based on a statistically significant population of observables. In the course of the project it became clear that the classical LH model cannot reproduce consistently all observations, and that the rates measured at high temperatures and large water partial pressures are actually faster than predicted by the LH model. The new BLH model is a more robust mathematical tool for prediction of oxidation rates over broad ranges of temperatures and water and hydrogen partial pressures.

All oxidation rate measurements are now completed for four grades of graphite (medium grained PCEA and NBG-17, and superfine gained IG-110 and 2114). The project continues with characterization of density profiles in specimens oxidized nonuniformly at well-defined conditions, and measurements of effective diffusivity coefficients of water vapor in the four grades of graphite. When all this information is available, it will be possible to develop comparative predictions on the behavior of these graphites in the HTGRs and to verify these predictions through direct measurements. 


\section{REFERENCES}

1. M P Kissane, A review of radionuclide behavior in the primary system of a very-high temperature reactor, Nucl. Eng. Design, 239 (2009) 3076-3091

2. $\mathrm{X} \mathrm{Yu}, \mathrm{S} \mathrm{Yu}$, Analysis of fuel element matrix graphite corrosion in HTR-PM for normal operating conditions, Nucl. Eng. Design, 240 (2010) 738-743.

3. E R Corwin, Generation IV Reactors Integrated Materials Technology Program Plan: Focus on Very High Temperature Reactor Materials, ORNL/TM-2008/129 (2008).

4. H G Olson, H L Brey, The Fort Saint Vrain high temperature gas cooled reactor, VI Evaluation and removal of primary coolant contaminants, Nucl Eng. Design 61 (1980) 315-322.

5. B Castle, NGNP Reactor Coolant Chemistry Control Study, INL/EXT-10-10533.

6. R N Wright, Kinetics of Gas Reactions and Environmental Degradation in NGNP Helium, INL/EXT-06-11494.

7. C Velasquez, G Hightower, R Burnette, The Oxidation of H-451 Graphite by Steam. Part 1: Reaction Kinetics, General Atomic Company, GA-A14951 (1978).

8. P L Walker, Jr, F Rusinko, Jr, L G Austin, Gas Reactions of Carbon, Adv. Catalysis 11 (1959) 133-221.

9. M B Richards, Reaction of nuclear grade graphite with low concentrations of steam in the helium coolant of an MHTGR, Energy 15 (1990) 729-739.

10. C. I. Contescu, T. Guldan, P. Wang, T. D. Burchell, The effect of microstructure on air oxidation resistance of nuclear graphite, Carbon 50 (2012) 3354-3366.

11. W-K Choi, B-J Kim, E-S Kim, S-H Chi, S-J Park, Oxidation behavior of IG and NBG graphites, Nucl Eng Design, 241 (2011) 82-87.

12. M S El-Genk, J-M P Tournier, Comparison of oxidation model predictions with gasification data of IG-110, IG-430 and NBG-25 nuclear graphite, J Nucl Mater 429 (2012) 141-158.

13. W-H Huang, S-C Tsai, C-W Yang, J-J Kai, The relationship between microstructure and oxidation effects of selected IG- and NBG-grade nuclear graphites, J Nucl Mater 454 (2014) 149158

14. M Eto, T Kurosawa, Estimation of graphite materials corrosion with water-vapor in coolant of VHTR and oxidation effect on the materials properties. Specialists' Meeting on Graphite Component Structural Design. JAERI Tokai (Japan) September 8-11, 1986, IWGGR-11: 189194.

15. X Yu, L Brissoneau, C Bourdeloie, S Yu, The modeling of graphite oxidation behavior for HTGR fuel coolant channels under normal operating conditions, Nucl Eng Design 238 (2008) 22302238.

16. X Luo, X Yu, S Yu, J-C Robin, Analysis of graphite gasification by water vapor at different conversions, Nucl Eng Design 273 (2014) 68-74.

17. M M Stempniewicz, Correlation for steam-graphite reaction, Nucl Eng Design 280 (2014) 287293.

18. $\mathrm{Yu}, \mathrm{S} \mathrm{Yu}$, Analysis of fuel element matrix graphite corrosion in HTR-PM for normal operating conditions, Nucl Eng Design 240 (2010) 738-743.

19. M Richards, REACT_COMPACT: A computer code for modeling graphite corrosion and fuel hydrolysis, in HTR2016, International Topical Meeting on High Temperature Reactor Technology, Las Vegas, NV, November 6-10, 2016.

20. C I Contescu, Current progress in determining oxidation results of graphite grade 2114, Electronic Letter Report submitted to Idaho National Laboratory in completion of deliverable 4.3.A according to HTR Graphite R\&D ORNL FY 2017 MPO (July 2017).

21. C I Contescu, R Mee, Status of chronic oxidation studies of graphite, ORNL/TM-2016/195. 
22. C I Contescu, R W Mee, Y (JJ) Lee, J D Arregui-Mena, N C Gallego, T D Burchell, J J Kane, W E Windes, Beyond the classical kinetic model for chronic graphite oxidation by moisture in hightemperature gas-cooled reactors, Carbon 127 (2018) 158-169; 140 (2018) 249.

23. T H Hurt, J M Calo, Semi-global intrinsic kinetics for char combustion modeling, Combustion and Flame, 125 (2001) 138-1149.

24. https://www.graphite-eng.com/uploads/downloads/continuous casting_brochure.pdf (accessed 10/17/2018).

25. C. I. Contescu, T. D. Burchell, R. W. Mee, Accelerated oxidation studies of PCEA nuclear graphite by low concentrations of water and hydrogen in helium, ORNL/TM-2013/524 (2013).

26. C.I. Contescu, R.W. Mee, P. Wang, A.V. Romanova, T.D. Burchell, Oxidation of PCEA nuclear graphite by low water concentrations in helium, J. Nucl. Mater. 453 (2014) 225-232.

27. C.I. Contescu, T.D. Burchell, R.W. Mee, Kinetics of chronic oxidation of NBG-17 nuclear graphite by water vapor, ORNL/TM-2015/142 (2015). 
This page was intentionally left blank 
APPENDIX A

PHYSICAL MEASUREMENTS AND TEST CONDITIONS

\begin{tabular}{|c|c|c|c|c|c|c|c|c|c|c|c|}
\hline \multirow[b]{2}{*}{ Test Date } & \multirow[b]{2}{*}{ Specimen ID } & \multicolumn{4}{|c|}{ BEFORE TEST } & \multicolumn{2}{|c|}{ CONDITIONS } & \multicolumn{4}{|c|}{ AFTER TEST } \\
\hline & & $\begin{array}{c}\text { Weight } \\
\text { mg }\end{array}$ & $\begin{array}{c}\text { Average L } \\
\mathrm{mm}\end{array}$ & $\begin{array}{c}\text { Average D } \\
\mathrm{mm}\end{array}$ & $\begin{array}{c}\text { Density } \\
\mathrm{g} / \mathrm{cm}^{3}\end{array}$ & $\begin{array}{c}\mathrm{P}_{\mathrm{H} 2 \mathrm{O}} \\
\mathrm{Pa} \\
\end{array}$ & $\begin{array}{l}\mathrm{P}_{\mathrm{H} 2} \\
\mathrm{~Pa} \\
\end{array}$ & $\begin{array}{c}\text { Weight } \\
\mathrm{mg}\end{array}$ & $\begin{array}{c}\text { Average } L \\
\mathrm{~mm}\end{array}$ & $\begin{array}{c}\text { Average D } \\
\mathrm{mm}\end{array}$ & $\begin{array}{c}\text { Density } \\
\mathrm{g} / \mathrm{cm}^{3}\end{array}$ \\
\hline $11 / 16 / 2016$ & $M-1$ & 897.15 & 25.01 & 5.01 & 1.825 & 200 & 0 & 886.86 & 25.00 & 5.01 & 1.804 \\
\hline $11 / 21 / 2016$ & $M-2$ & 901.27 & 25.01 & 5.02 & 1.821 & 200 & 0 & 891.55 & 25.00 & 5.01 & 1.807 \\
\hline $11 / 23 / 2016$ & $M-3$ & 901.67 & 25.00 & 5.02 & 1.827 & 100 & 0 & 895.75 & 25.01 & 5.02 & 1.813 \\
\hline $11 / 30 / 2016$ & $M-4$ & 900.32 & 24.99 & 5.01 & 1.827 & 50 & 0 & 897.08 & 25.00 & 5.01 & 1.819 \\
\hline $12 / 15 / 2016$ & $M-5$ & 886.41 & 24.99 & 4.99 & 1.813 & 150 & 0 & 879.12 & 24.99 & 4.99 & 1.803 \\
\hline $12 / 19 / 2016$ & M-6 & 895.45 & 25.02 & 5.01 & 1.819 & 25 & 0 & 893.77 & 25.02 & 5.01 & 1.812 \\
\hline $12 / 21 / 2016$ & $M-7$ & 886.86 & 25.01 & 5.00 & 1.805 & 500 & 0 & 881.11 & 25.00 & 5.00 & 1.795 \\
\hline 1/9/2017 & $M-8$ & 900.43 & 25.01 & 5.00 & 1.832 & 25 & 0 & 898.69 & 25.02 & 5.01 & 1.822 \\
\hline $1 / 11 / 2017$ & $M-9$ & 885.25 & 24.98 & 4.99 & 1.817 & 250 & 0 & 875.00 & 24.99 & 4.98 & 1.802 \\
\hline $1 / 23 / 2017$ & $M-10$ & 892.93 & 24.98 & 5.00 & 1.825 & 100 & 0 & 887.28 & 24.99 & 5.00 & 1.810 \\
\hline $1 / 24 / 2017$ & $M-11$ & 896.32 & 24.94 & 5.00 & 1.828 & 200 & 0 & 887.89 & 24.95 & 5.01 & 1.810 \\
\hline $1 / 30 / 2017$ & $M-12$ & 892.51 & 24.99 & 4.99 & 1.824 & 400 & 0 & 885.06 & 25.00 & 4.99 & 1.812 \\
\hline 2/1/2017 & $M-13$ & 897.79 & 24.97 & 5.01 & 1.823 & 400 & 0 & 881.13 & 24.99 & 5.02 & 1.786 \\
\hline $2 / 3 / 2017$ & $M-14$ & 898.83 & 24.99 & 5.02 & 1.815 & 600 & 0 & 871.03 & 24.99 & 5.02 & 1.765 \\
\hline $2 / 6 / 2017$ & $M-15$ & 896.01 & 25.01 & 5.02 & 1.815 & 50 & 0 & 894.67 & 24.99 & 4.99 & 1.830 \\
\hline $2 / 8 / 2017$ & $M-16$ & 883.06 & 25.01 & 4.97 & 1.819 & 150 & 0 & 873.99 & 24.99 & 4.97 & 1.802 \\
\hline $2 / 9 / 2017$ & $M-17$ & 896.99 & 24.98 & 5.01 & 1.821 & 0 & 0 & 896.13 & 25.00 & 5.01 & 1.822 \\
\hline $2 / 13 / 2017$ & $M-18$ & 881.95 & 24.99 & 4.99 & 1.806 & 650 & 0 & 853.15 & 25.00 & 4.98 & 1.755 \\
\hline $2 / 20 / 2017$ & M-19 & 891.34 & 24.98 & 5.00 & 1.816 & 30 & 0 & 889.79 & 24.98 & 5.00 & 1.818 \\
\hline $2 / 23 / 2017$ & $M-20$ & 891.64 & 24.96 & 5.01 & 1.815 & 80 & 0 & 884.68 & 24.97 & 4.99 & 1.812 \\
\hline $2 / 24 / 2017$ & $M-21$ & 897.89 & 25.01 & 5.02 & 1.819 & 0 & 0 & 896.97 & 25.01 & 5.02 & 1.816 \\
\hline
\end{tabular}




\begin{tabular}{|c|c|c|c|c|c|c|c|c|c|c|c|}
\hline \multirow[b]{2}{*}{ Test Date } & \multirow[b]{2}{*}{ Specimen ID } & \multicolumn{4}{|c|}{ BEFORE TEST } & \multicolumn{2}{|c|}{ CONDITIONS } & \multicolumn{4}{|c|}{ AFTER TEST } \\
\hline & & $\begin{array}{c}\text { Weight } \\
\text { mg }\end{array}$ & $\begin{array}{c}\text { Average L } \\
\mathrm{mm}\end{array}$ & $\begin{array}{c}\text { Average } D \\
\mathrm{~mm}\end{array}$ & $\begin{array}{l}\text { Density } \\
\mathrm{g} / \mathrm{cm}^{3}\end{array}$ & $\begin{array}{c}\mathrm{P}_{\mathrm{H} 2 \mathrm{O}} \\
\mathrm{Pa}\end{array}$ & $\begin{array}{l}\mathrm{P}_{\mathrm{H} 2} \\
\mathrm{~Pa}\end{array}$ & $\begin{array}{c}\text { Weight } \\
\text { mg }\end{array}$ & $\begin{array}{c}\text { Average } L \\
\mathrm{~mm}\end{array}$ & $\begin{array}{c}\text { Average D } \\
\mathrm{mm}\end{array}$ & $\begin{array}{c}\text { Density } \\
\mathrm{g} / \mathrm{cm}^{3}\end{array}$ \\
\hline $2 / 27 / 2017$ & $M-22$ & 895.83 & 25.04 & 5.01 & 1.818 & 700 & 0 & 872.35 & 25.11 & 5.02 & 1.759 \\
\hline $2 / 28 / 2017$ & $M-23$ & 890.69 & 25.03 & 5.00 & 1.816 & 35 & 0 & 890.09 & 25.03 & 5.00 & 1.816 \\
\hline $3 / 1 / 2017$ & $M-24$ & 898.05 & 25.03 & 5.02 & 1.812 & 35 & 0 & 896.31 & 25.04 & 5.03 & 1.806 \\
\hline $3 / 8 / 2017$ & $M-25$ & 903.07 & 25.00 & 5.03 & 1.820 & 300 & 15 & 890.51 & 25.00 & 5.04 & 1.788 \\
\hline $3 / 9 / 2017$ & $M-26$ & 890.22 & 24.98 & 5.00 & 1.819 & 100 & 30 & 886.96 & 25.00 & 4.99 & 1.813 \\
\hline $3 / 13 / 2017$ & $M-27$ & 897.72 & 24.99 & 5.02 & 1.818 & 50 & 45 & 892.03 & 25.00 & 5.02 & 1.806 \\
\hline $3 / 14 / 2017$ & $M-28$ & 892.03 & 24.98 & 5.00 & 1.822 & 20 & 90 & 891.38 & 24.99 & 4.99 & 1.823 \\
\hline $3 / 16 / 2017$ & $M-29$ & 899.59 & 25.00 & 5.01 & 1.826 & 3 & 15 & 899.40 & 25.01 & 5.00 & 1.832 \\
\hline $3 / 20 / 2017$ & $M-30$ & 897.05 & 24.98 & 5.02 & 1.818 & 300 & 30 & 888.89 & 24.98 & 5.01 & 1.810 \\
\hline $3 / 21 / 2017$ & $M-31$ & 903.81 & 25.00 & 5.03 & 1.819 & 100 & 45 & 900.99 & 25.01 & 5.02 & 1.822 \\
\hline $3 / 23 / 2017$ & $M-32$ & 893.97 & 24.99 & 5.00 & 1.821 & 50 & 90 & 893.67 & 25.00 & 5.00 & 1.821 \\
\hline $3 / 24 / 2017$ & $M-33$ & 899.54 & 24.98 & 5.02 & 1.820 & 3 & 15 & 899.19 & 24.99 & 5.03 & 1.814 \\
\hline $4 / 25 / 2017$ & $M-34$ & 892.36 & 25.00 & 5.00 & 1.820 & 20 & 15 & 891.33 & 25.01 & 4.99 & 1.821 \\
\hline $5 / 1 / 2017$ & M-35 & 894.61 & 25.00 & 5.01 & 1.819 & 20 & 15 & 893.95 & 25.00 & 5.00 & 1.820 \\
\hline $5 / 4 / 2017$ & $M-36$ & 890.26 & 24.99 & 5.00 & 1.819 & 300 & 45 & 889.96 & 25.00 & 4.99 & 1.818 \\
\hline $5 / 8 / 2017$ & $M-37$ & 901.42 & 24.99 & 5.02 & 1.823 & 300 & 45 & 889.29 & 25.00 & 5.01 & 1.803 \\
\hline $5 / 10 / 2017$ & $M-38$ & 905.69 & 24.98 & 5.01 & 1.842 & 100 & 90 & 904.82 & 25.02 & 5.04 & 1.814 \\
\hline $5 / 11 / 2017$ & $M-39$ & 895.31 & 25.00 & 5.01 & 1.820 & 50 & 30 & 894.79 & 24.98 & 4.99 & 1.833 \\
\hline $5 / 15 / 2017$ & $M-40$ & 896.80 & 24.99 & 5.01 & 1.820 & 50 & 15 & 895.99 & 25.00 & 5.02 & 1.814 \\
\hline $5 / 16 / 2017$ & $M-41$ & 894.64 & 24.98 & 5.01 & 1.819 & 20 & 30 & 894.04 & 24.99 & 5.01 & 1.815 \\
\hline $5 / 18 / 2017$ & $M-42$ & 901.59 & 24.97 & 5.03 & 1.817 & 300 & 90 & 898.47 & 24.99 & 5.03 & 1.811 \\
\hline $5 / 22 / 2017$ & $M-43$ & 893.54 & 24.97 & 5.00 & 1.822 & 100 & 15 & 891.17 & 24.99 & 5.00 & 1.814 \\
\hline $6 / 14 / 2017$ & $M-44$ & 892.82 & 24.96 & 4.99 & 1.827 & 300 & 0 & 849.08 & 24.97 & 4.99 & 1.743 \\
\hline $6 / 26 / 2017$ & $M-45$ & 895.20 & 25.00 & 5.00 & 1.825 & 300 & 0 & 849.92 & 24.97 & 4.95 & 1.770 \\
\hline $6 / 30 / 2017$ & $M-46$ & 895.65 & 24.98 & 5.01 & 1.820 & 300 & 0 & 848.38 & 24.98 & 5.01 & 1.727 \\
\hline $8 / 3 / 2017$ & $M-47$ & 889.58 & 24.99 & 4.99 & 1.821 & 300 & 0 & 837.49 & 24.98 & 4.98 & 1.724 \\
\hline
\end{tabular}


APPENDIX B

\section{LOG OF EXPERIMENTAL RESULTS}

\begin{tabular}{|c|c|c|c|c|c|c|c|c|c|c|c|c|c|c|c|c|c|}
\hline \multirow{3}{*}{$\begin{array}{l}\text { Data } \\
\text { No. }\end{array}$} & \multirow{3}{*}{ Test date } & \multirow{3}{*}{$\begin{array}{c}\text { Spec. } \\
\text { ID }\end{array}$} & \multicolumn{2}{|c|}{$\mathrm{P}_{\mathrm{H} 2 \mathrm{O}}$} & \multirow{2}{*}{$\mathrm{P}_{\mathrm{H} 2}$} & \multirow{2}{*}{ Temp } & \multicolumn{2}{|c|}{ Weight } & \multicolumn{2}{|c|}{ Time in test } & \multirow[t]{2}{*}{ Rate } & \multicolumn{2}{|c|}{ Weight loss } & \multicolumn{3}{|c|}{ Preparation } & \multirow{2}{*}{ Notes } \\
\hline & & & target & actual & & & before & after & before & after & & before & after & time & temp & $\begin{array}{l}\text { wt. } \\
\text { loss }\end{array}$ & \\
\hline & & & $\mathrm{Pa}$ & $\mathrm{Pa}$ & $\mathrm{Pa}$ & ${ }^{\circ} \mathrm{C}$ & $\mathrm{mg}$ & $\mathrm{mg}$ & $\mathrm{h}$ & $\mathrm{h}$ & $\mathrm{s}^{-1}$ & $\%$ & $\%$ & $\mathrm{~h}$ & ${ }^{\circ} \mathrm{C}$ & $\mathrm{mg}$ & \\
\hline 1 & $11 / 17 / 16$ & M-1 & 200 & 202 & 0 & 800 & 897.04 & 897.02 & 5.91 & 8.34 & 3.19E-09 & 0.000 & 0.003 & 1 & 1200 & 0.050 & \\
\hline 2 & $11 / 17 / 16$ & M-1 & 200 & 181 & 0 & 850 & 897.02 & 896.97 & 8.83 & 11.40 & $5.66 \mathrm{E}-09$ & 0.003 & 0.008 & 1 & 1200 & 0.050 & \\
\hline 3 & $11 / 17 / 16$ & M-1 & 200 & 191 & 0 & 900 & 896.97 & 896.89 & 11.92 & 14.42 & $1.04 \mathrm{E}-08$ & 0.008 & 0.017 & 1 & 1200 & 0.050 & \\
\hline 4 & $11 / 17 / 16$ & $M-1$ & 200 & 191 & 0 & 950 & 896.89 & 896.65 & 14.91 & 17.54 & $2.86 \mathrm{E}-08$ & 0.017 & 0.044 & 1 & 1200 & 0.050 & \\
\hline 5 & $11 / 17 / 16$ & $M-1$ & 200 & 193 & 0 & 1000 & 896.65 & 895.89 & 18.03 & 20.67 & $8.82 \mathrm{E}-08$ & 0.044 & 0.128 & 1 & 1200 & 0.050 & \\
\hline 6 & $11 / 17 / 16$ & $M-1$ & 200 & 193 & 0 & 1050 & 895.89 & 893.60 & 21.09 & 23.69 & $2.73 \mathrm{E}-07$ & 0.128 & 0.384 & 1 & 1200 & 0.050 & \\
\hline 7 & $11 / 17 / 16$ & $M-1$ & 200 & 179 & 1 & 1100 & 893.60 & 888.15 & 24.14 & 26.97 & 5.99E-07 & 0.384 & 0.992 & 1 & 1200 & 0.050 & \\
\hline 8 & $11 / 21 / 16$ & $M-2$ & 200 & 225 & 0 & 800 & 900.94 & 900.92 & 5.46 & 7.24 & 3.64E-09 & 0.000 & 0.002 & 1 & 1200 & 0.078 & \\
\hline 9 & $11 / 21 / 16$ & $M-2$ & 200 & 238 & 0 & 850 & 900.92 & 900.87 & 7.79 & 10.41 & 5.77E-09 & 0.002 & 0.008 & 1 & 1200 & 0.078 & \\
\hline 10 & $11 / 21 / 16$ & $M-2$ & 200 & 245 & 0 & 900 & 900.87 & 900.80 & 10.91 & 13.43 & 8.44E-09 & 0.008 & 0.015 & 1 & 1200 & 0.078 & \\
\hline 11 & $11 / 21 / 16$ & $M-2$ & 200 & 244 & 0 & 950 & 900.80 & 900.65 & 13.92 & 16.57 & $1.70 \mathrm{E}-08$ & 0.015 & 0.032 & 1 & 1200 & 0.078 & \\
\hline 12 & $11 / 21 / 16$ & $M-2$ & 200 & 243 & 0 & 1000 & 900.65 & 900.11 & 17.06 & 19.52 & $6.76 \mathrm{E}-08$ & 0.032 & 0.091 & 1 & 1200 & 0.078 & \\
\hline 13 & $11 / 21 / 16$ & $M-2$ & 200 & 216 & 0 & 1050 & 900.11 & 897.98 & 20.14 & 22.76 & $2.51 \mathrm{E}-07$ & 0.091 & 0.328 & 1 & 1200 & 0.078 & \\
\hline 14 & $11 / 21 / 16$ & $M-2$ & 200 & 220 & 1 & 1100 & 897.98 & 892.42 & 23.04 & 25.93 & 5.95E-07 & 0.328 & 0.945 & 1 & 1200 & 0.078 & \\
\hline 15 & $11 / 23 / 16$ & $M-3$ & 100 & 135 & 0 & 800 & 901.65 & 901.62 & 4.84 & 7.24 & 2.95E-09 & 0.000 & 0.003 & 1 & 1200 & 0.089 & \\
\hline 16 & $11 / 23 / 16$ & $M-3$ & 100 & 135 & 0 & 850 & 901.62 & 901.58 & 7.68 & 10.49 & $5.04 \mathrm{E}-09$ & 0.003 & 0.008 & 1 & 1200 & 0.089 & \\
\hline 17 & $11 / 23 / 16$ & $M-3$ & 100 & 138 & 0 & 900 & 901.58 & 901.52 & 10.83 & 13.43 & $6.99 \mathrm{E}-09$ & 0.008 & 0.014 & 1 & 1200 & 0.089 & \\
\hline 18 & $11 / 23 / 16$ & $M-3$ & 100 & 130 & 0 & 950 & 901.52 & 901.40 & 13.89 & 18.55 & 8.07E-09 & 0.014 & 0.028 & 1 & 1200 & 0.089 & \\
\hline
\end{tabular}


ORNL/TM-2018/1057

\begin{tabular}{|c|c|c|c|c|c|c|c|c|c|c|c|c|c|c|c|c|c|}
\hline \multirow{3}{*}{$\begin{array}{l}\text { Data } \\
\text { No. }\end{array}$} & \multirow{3}{*}{ Test date } & \multirow{3}{*}{$\begin{array}{c}\text { Spec. } \\
\text { ID }\end{array}$} & \multicolumn{2}{|c|}{$\mathrm{P}_{\mathrm{H} 2 \mathrm{O}}$} & \multirow{2}{*}{$P_{\mathrm{H} 2}$} & \multirow{2}{*}{ Temp } & \multicolumn{2}{|c|}{ Weight } & \multicolumn{2}{|c|}{ Time in test } & \multirow[t]{2}{*}{ Rate } & \multicolumn{2}{|c|}{ Weight loss } & \multicolumn{3}{|c|}{ Preparation } & \multirow{2}{*}{ Notes } \\
\hline & & & target & actual & & & before & after & before & after & & before & after & time & temp & $\begin{array}{l}\text { wt. } \\
\text { loss }\end{array}$ & \\
\hline & & & $\mathrm{Pa}$ & $\mathrm{Pa}$ & $\mathrm{Pa}$ & ${ }^{\circ} \mathrm{C}$ & $\mathrm{mg}$ & $\mathrm{mg}$ & $\mathrm{h}$ & $\mathrm{h}$ & $\mathrm{s}^{-1}$ & $\%$ & $\%$ & $\mathrm{~h}$ & ${ }^{\circ} \mathrm{C}$ & $\mathrm{mg}$ & \\
\hline 19 & $11 / 23 / 16$ & $M-3$ & 100 & 122 & 0 & 1000 & 901.40 & 901.02 & 17.05 & 19.68 & $4.48 \mathrm{E}-08$ & 0.028 & 0.070 & 1 & 1200 & 0.089 & \\
\hline 20 & $11 / 23 / 16$ & $M-3$ & 100 & 120 & 0 & 1050 & 901.02 & 899.81 & 20.14 & 22.64 & $1.48 \mathrm{E}-07$ & 0.070 & 0.203 & 1 & 1200 & 0.089 & \\
\hline 21 & $11 / 23 / 16$ & $M-3$ & 100 & 120 & 1 & 1100 & 899.81 & 896.67 & 23.11 & 25.83 & 3.57E-07 & 0.203 & 0.552 & 1 & 1200 & 0.089 & \\
\hline 22 & $11 / 30 / 16$ & M-4 & 50 & 56 & 0 & 800 & 900.26 & 900.24 & 6.07 & 7.95 & $3.28 \mathrm{E}-09$ & 0.000 & 0.002 & 1 & 1200 & 0.057 & \\
\hline 23 & $11 / 30 / 16$ & M-4 & 50 & 57 & 0 & 850 & 900.24 & 900.19 & 8.27 & 10.97 & $5.49 \mathrm{E}-09$ & 0.002 & 0.008 & 1 & 1200 & 0.057 & \\
\hline 24 & $11 / 30 / 16$ & M-4 & 50 & 56 & 0 & 900 & 900.19 & 900.13 & 11.26 & 14.00 & $6.98 \mathrm{E}-09$ & 0.008 & 0.014 & 1 & 1200 & 0.057 & \\
\hline 25 & $11 / 30 / 16$ & $M-4$ & 50 & 56 & 0 & 950 & 900.13 & 900.03 & 14.44 & 17.12 & $1.14 \mathrm{E}-08$ & 0.014 & 0.025 & 1 & 1200 & 0.057 & \\
\hline 26 & $11 / 30 / 16$ & $M-4$ & 50 & 56 & 0 & 1000 & 900.03 & 899.83 & 17.66 & 20.14 & $2.46 \mathrm{E}-08$ & 0.025 & 0.047 & 1 & 1200 & 0.057 & \\
\hline 27 & $11 / 30 / 16$ & $M-4$ & 50 & 56 & 0 & 1050 & 899.83 & 899.27 & 20.62 & 23.17 & $6.82 \mathrm{E}-08$ & 0.047 & 0.110 & 1 & 1200 & 0.057 & \\
\hline 28 & $11 / 30 / 16$ & $M-4$ & 50 & 56 & 0 & 1100 & 899.27 & 897.57 & 23.55 & 26.44 & $1.81 \mathrm{E}-07$ & 0.110 & 0.298 & 1 & 1200 & 0.057 & \\
\hline 29 & $12 / 15 / 16$ & M-5 & 150 & 154 & 0 & 800 & 885.91 & 885.88 & 6.11 & 7.79 & 5.79E-09 & 0.000 & 0.003 & 1 & 1200 & 0.176 & \\
\hline 30 & $12 / 15 / 16$ & $M-5$ & 150 & 163 & 0 & 850 & 885.88 & 885.82 & 8.30 & 10.82 & $6.84 \mathrm{E}-09$ & 0.003 & 0.010 & 1 & 1200 & 0.176 & \\
\hline 31 & $12 / 15 / 16$ & $M-5$ & 150 & 163 & 0 & 900 & 885.82 & 885.74 & 11.39 & 14.00 & $1.05 \mathrm{E}-08$ & 0.010 & 0.020 & 1 & 1200 & 0.176 & \\
\hline 32 & $12 / 15 / 16$ & $M-5$ & 150 & 162 & 0 & 950 & 885.74 & 885.59 & 14.38 & 16.93 & $1.78 \mathrm{E}-08$ & 0.020 & 0.036 & 1 & 1200 & 0.176 & \\
\hline 33 & $12 / 15 / 16$ & $M-5$ & 150 & 155 & 0 & 1000 & 885.59 & 885.12 & 17.50 & 20.14 & $5.66 \mathrm{E}-08$ & 0.036 & 0.090 & 1 & 1200 & 0.176 & \\
\hline 34 & $12 / 15 / 16$ & $M-5$ & 150 & 159 & 0 & 1050 & 885.12 & 883.67 & 20.59 & 23.01 & $1.87 \mathrm{E}-07$ & 0.090 & 0.253 & 1 & 1200 & 0.176 & \\
\hline 35 & $12 / 15 / 16$ & $M-5$ & 150 & 161 & 0 & 1100 & 883.67 & 879.93 & 23.61 & 26.38 & $4.24 \mathrm{E}-07$ & 0.253 & 0.674 & 1 & 1200 & 0.176 & \\
\hline 36 & $12 / 19 / 16$ & M-6 & 25 & 28 & 0 & 800 & 895.91 & 895.89 & 5.19 & 7.68 & $3.24 \mathrm{E}-09$ & 0.000 & 0.003 & 1 & 1200 & 0.080 & \\
\hline 37 & $12 / 19 / 16$ & M-6 & 25 & 18 & 0 & 850 & 895.89 & 895.84 & 8.35 & 10.80 & 5.95E-09 & 0.003 & 0.008 & 1 & 1200 & 0.080 & \\
\hline 38 & $12 / 19 / 16$ & M-6 & 25 & 18 & 0 & 900 & 895.84 & 895.78 & 11.58 & 13.89 & $8.46 \mathrm{E}-09$ & 0.008 & 0.015 & 1 & 1200 & 0.080 & \\
\hline 39 & $12 / 19 / 16$ & M-6 & 25 & 18 & 0 & 950 & 895.78 & 895.69 & 14.41 & 16.90 & $1.10 \mathrm{E}-08$ & 0.015 & 0.025 & 1 & 1200 & 0.080 & \\
\hline 40 & $12 / 19 / 16$ & M-6 & 25 & 18 & 0 & 1000 & 895.69 & 895.55 & 17.53 & 20.09 & $1.64 \mathrm{E}-08$ & 0.025 & 0.040 & 1 & 1200 & 0.080 & \\
\hline 41 & $12 / 19 / 16$ & M-6 & 25 & 18 & 0 & 1050 & 895.55 & 895.28 & 20.65 & 23.32 & $3.18 \mathrm{E}-08$ & 0.040 & 0.071 & 1 & 1200 & 0.080 & \\
\hline 42 & $12 / 19 / 16$ & M-6 & 25 & 18 & 0 & 1100 & 895.28 & 894.68 & 23.51 & 26.22 & $6.85 \mathrm{E}-08$ & 0.071 & 0.137 & 1 & 1200 & 0.080 & \\
\hline 43 & $12 / 21 / 16$ & $M-7$ & 500 & 416 & 0 & 800 & 886.79 & 886.78 & 5.66 & 7.10 & $2.18 \mathrm{E}-09$ & 0.007 & 0.009 & 1 & 1200 & 0.112 & \\
\hline 44 & $12 / 21 / 16$ & $M-7$ & 500 & 420 & 0 & 850 & 886.78 & 886.75 & 8.63 & 10.52 & $5.80 \mathrm{E}-09$ & 0.009 & 0.013 & 1 & 1200 & 0.112 & \\
\hline
\end{tabular}


ORNL/TM-2018/1057

\begin{tabular}{|c|c|c|c|c|c|c|c|c|c|c|c|c|c|c|c|c|c|}
\hline \multirow{3}{*}{$\begin{array}{l}\text { Data } \\
\text { No. }\end{array}$} & \multirow{3}{*}{ Test date } & \multirow{3}{*}{$\begin{array}{c}\text { Spec. } \\
\text { ID }\end{array}$} & \multicolumn{2}{|c|}{$\mathrm{P}_{\mathrm{H} 2 \mathrm{O}}$} & \multirow{2}{*}{$P_{\mathrm{H} 2}$} & \multirow{2}{*}{ Temp } & \multicolumn{2}{|c|}{ Weight } & \multicolumn{2}{|c|}{ Time in test } & \multirow[t]{2}{*}{ Rate } & \multicolumn{2}{|c|}{ Weight loss } & \multicolumn{3}{|c|}{ Preparation } & \multirow{2}{*}{ Notes } \\
\hline & & & target & actual & & & before & after & before & after & & before & after & time & temp & $\begin{array}{l}\text { wt. } \\
\text { loss }\end{array}$ & \\
\hline & & & $\mathrm{Pa}$ & $\mathrm{Pa}$ & $\mathrm{Pa}$ & ${ }^{\circ} \mathrm{C}$ & $\mathrm{mg}$ & $\mathrm{mg}$ & $\mathrm{h}$ & $\mathrm{h}$ & $\mathrm{s}^{-1}$ & $\%$ & $\%$ & $\mathrm{~h}$ & ${ }^{\circ} \mathrm{C}$ & $\mathrm{mg}$ & \\
\hline 45 & $12 / 21 / 16$ & $M-7$ & 500 & 453 & 0 & 900 & 886.75 & 886.72 & 11.35 & 12.76 & 7.55E-09 & 0.013 & 0.016 & 1 & 1200 & 0.112 & \\
\hline 46 & $12 / 21 / 16$ & $M-7$ & 500 & 455 & 0 & 950 & 886.72 & 886.67 & 14.37 & 15.09 & $1.78 \mathrm{E}-08$ & 0.016 & 0.021 & 1 & 1200 & 0.112 & \\
\hline 47 & $12 / 21 / 16$ & $M-7$ & 500 & 629 & 0 & 1000 & 886.67 & 886.33 & 19.23 & 20.01 & $1.38 \mathrm{E}-07$ & 0.021 & 0.060 & 1 & 1200 & 0.112 & \\
\hline 48 & $12 / 21 / 16$ & $M-7$ & 500 & 454 & 0 & 1050 & 886.33 & 885.49 & 22.32 & 22.90 & $4.54 \mathrm{E}-07$ & 0.060 & 0.154 & 1 & 1200 & 0.112 & \\
\hline 49 & 01/09/17 & M-8 & 25 & 67 & 0 & 800 & 900.08 & 900.04 & 5.21 & 7.70 & 4.21E-09 & 0.039 & 0.043 & 1 & 1200 & 0.130 & \\
\hline 50 & 01/09/17 & M-8 & 25 & 69 & 0 & 850 & 900.04 & 899.99 & 8.32 & 10.74 & $6.50 \mathrm{E}-09$ & 0.043 & 0.049 & 1 & 1200 & 0.130 & \\
\hline 51 & 01/09/17 & $M-8$ & 25 & 67 & 0 & 900 & 899.99 & 899.91 & 11.36 & 13.80 & 9.87E-09 & 0.049 & 0.057 & 1 & 1200 & 0.130 & \\
\hline 52 & 01/09/17 & $M-8$ & 25 & 43 & 0 & 950 & 899.91 & 899.79 & 14.42 & 17.06 & $1.43 \mathrm{E}-08$ & 0.057 & 0.071 & 1 & 1200 & 0.130 & \\
\hline 53 & 01/09/17 & $M-8$ & 25 & 15 & 0 & 1000 & 899.79 & 899.65 & 17.47 & 19.98 & $1.76 \mathrm{E}-08$ & 0.071 & 0.087 & 1 & 1200 & 0.130 & \\
\hline 54 & 01/09/17 & $M-8$ & 25 & 15 & 0 & 1050 & 899.65 & 899.49 & 21.66 & 23.14 & $3.23 \mathrm{E}-08$ & 0.087 & 0.104 & 1 & 1200 & 0.130 & \\
\hline 55 & 01/09/17 & M-8 & 25 & 14 & 0 & 1100 & 899.49 & 899.09 & 24.24 & 26.20 & $6.37 \mathrm{E}-08$ & 0.104 & 0.149 & 1 & 1200 & 0.130 & \\
\hline 56 & $01 / 12 / 17$ & $M-9$ & 250 & 262 & 0 & 800 & 884.96 & 884.94 & 4.64 & 7.67 & $1.45 \mathrm{E}-09$ & 0.033 & 0.035 & 1 & 1200 & 0.084 & \\
\hline 57 & $01 / 12 / 17$ & $M-9$ & 250 & 276 & 0 & 850 & 884.94 & 884.92 & 8.24 & 10.66 & 3.76E-09 & 0.035 & 0.038 & 1 & 1200 & 0.084 & \\
\hline 58 & $01 / 12 / 17$ & $M-9$ & 250 & 292 & 0 & 900 & 884.92 & 884.86 & 11.50 & 13.92 & $6.75 \mathrm{E}-09$ & 0.038 & 0.044 & 1 & 1200 & 0.084 & \\
\hline 59 & $01 / 12 / 17$ & M-9 & 250 & 298 & 0 & 950 & 884.86 & 884.72 & 14.41 & 17.01 & $1.68 \mathrm{E}-08$ & 0.044 & 0.059 & 1 & 1200 & 0.084 & \\
\hline 60 & $01 / 12 / 17$ & $M-9$ & 250 & 276 & 0 & 1000 & 884.72 & 884.15 & 17.84 & 20.05 & $8.23 \mathrm{E}-08$ & 0.059 & 0.125 & 1 & 1200 & 0.084 & \\
\hline 61 & $01 / 12 / 17$ & M-9 & 250 & 264 & 0 & 1050 & 884.15 & 882.12 & 20.79 & 23.00 & $2.88 \mathrm{E}-07$ & 0.125 & 0.354 & 1 & 1200 & 0.084 & \\
\hline 62 & $01 / 12 / 17$ & $M-9$ & 250 & 266 & 0 & 1100 & 882.12 & 876.97 & 23.66 & 26.21 & $6.35 \mathrm{E}-07$ & 0.354 & 0.935 & 1 & 1200 & 0.084 & \\
\hline 63 & $01 / 23 / 17$ & M-10 & 100 & 112 & 0 & 800 & 892.79 & 892.76 & 4.70 & 7.57 & $3.36 \mathrm{E}-09$ & 0.000 & 0.003 & 1 & 1200 & 0.102 & \\
\hline 64 & $01 / 23 / 17$ & $M-10$ & 100 & 117 & 0 & 850 & 892.76 & 892.72 & 8.23 & 10.78 & $5.25 \mathrm{E}-09$ & 0.003 & 0.008 & 1 & 1200 & 0.102 & \\
\hline 65 & $01 / 23 / 17$ & M-10 & 100 & 117 & 0 & 900 & 892.72 & 892.64 & 11.38 & 13.73 & $9.40 \mathrm{E}-09$ & 0.008 & 0.016 & 1 & 1200 & 0.102 & \\
\hline 66 & $01 / 23 / 17$ & M-10 & 100 & 114 & 0 & 950 & 892.64 & 892.52 & 14.53 & 16.98 & $1.52 \mathrm{E}-08$ & 0.016 & 0.030 & 1 & 1200 & 0.102 & \\
\hline 67 & $01 / 23 / 17$ & $M-10$ & 100 & 110 & 0 & 1000 & 892.52 & 892.22 & 17.90 & 20.00 & $4.45 \mathrm{E}-08$ & 0.030 & 0.063 & 1 & 1200 & 0.102 & \\
\hline 68 & $01 / 23 / 17$ & $M-10$ & 100 & 108 & 0 & 1050 & 892.22 & 891.10 & 20.55 & 23.08 & $1.39 \mathrm{E}-07$ & 0.063 & 0.190 & 1 & 1200 & 0.102 & \\
\hline 69 & $01 / 23 / 17$ & $\mathrm{M}-10$ & 100 & 108 & 0 & 1100 & 891.10 & 888.71 & 23.88 & 26.17 & $3.25 \mathrm{E}-07$ & 0.190 & 0.457 & 1 & 1200 & 0.102 & \\
\hline 70 & $01 / 25 / 17$ & $M-11$ & 200 & 204 & 0 & 800 & 896.29 & 896.25 & 4.78 & 7.73 & 3.47E-09 & 0.000 & 0.004 & 1 & 1200 & 0.094 & \\
\hline
\end{tabular}


ORNL/TM-2018/1057

\begin{tabular}{|c|c|c|c|c|c|c|c|c|c|c|c|c|c|c|c|c|c|}
\hline \multirow{3}{*}{$\begin{array}{l}\text { Data } \\
\text { No. }\end{array}$} & \multirow{3}{*}{ Test date } & \multirow{3}{*}{$\begin{array}{c}\text { Spec. } \\
\text { ID }\end{array}$} & \multicolumn{2}{|c|}{$\mathrm{P}_{\mathrm{H} 2 \mathrm{O}}$} & \multirow{2}{*}{$P_{\mathrm{H} 2}$} & \multirow{2}{*}{ Temp } & \multicolumn{2}{|c|}{ Weight } & \multicolumn{2}{|c|}{ Time in test } & \multirow[t]{2}{*}{ Rate } & \multicolumn{2}{|c|}{ Weight loss } & \multicolumn{3}{|c|}{ Preparation } & \multirow{2}{*}{ Notes } \\
\hline & & & target & actual & & & before & after & before & after & & before & after & time & temp & $\begin{array}{l}\text { wt. } \\
\text { loss }\end{array}$ & \\
\hline & & & $\mathrm{Pa}$ & $\mathrm{Pa}$ & $\mathrm{Pa}$ & ${ }^{\circ} \mathrm{C}$ & $\mathrm{mg}$ & $\mathrm{mg}$ & $\mathrm{h}$ & $\mathrm{h}$ & $\mathrm{s}^{-1}$ & $\%$ & $\%$ & $\mathrm{~h}$ & ${ }^{\circ} \mathrm{C}$ & $\mathrm{mg}$ & \\
\hline 71 & $01 / 25 / 17$ & $M-11$ & 200 & 210 & 0 & 850 & 896.25 & 896.21 & 8.27 & 10.82 & 5.47E-09 & 0.004 & 0.009 & 1 & 1200 & 0.094 & \\
\hline 72 & $01 / 25 / 17$ & $M-11$ & 200 & 210 & 0 & 900 & 896.21 & 896.14 & 11.38 & 13.83 & $8.60 \mathrm{E}-09$ & 0.009 & 0.016 & 1 & 1200 & 0.094 & \\
\hline 73 & $01 / 25 / 17$ & $M-11$ & 200 & 208 & 0 & 950 & 896.14 & 896.02 & 14.65 & 16.90 & $1.64 \mathrm{E}-08$ & 0.016 & 0.030 & 1 & 1200 & 0.094 & \\
\hline 74 & $01 / 25 / 17$ & M-11 & 200 & 202 & 0 & 1000 & 896.02 & 895.63 & 18.00 & 19.88 & $6.55 \mathrm{E}-08$ & 0.030 & 0.074 & 1 & 1200 & 0.094 & \\
\hline 75 & $01 / 25 / 17$ & M-11 & 200 & 196 & 0 & 1050 & 895.63 & 894.41 & 21.08 & 22.72 & $2.31 \mathrm{E}-07$ & 0.074 & 0.210 & 1 & 1200 & 0.094 & \\
\hline 76 & $01 / 25 / 17$ & M-11 & 200 & 195 & 0 & 1100 & 894.41 & 890.48 & 23.88 & 26.27 & $5.10 \mathrm{E}-07$ & 0.210 & 0.648 & 1 & 1200 & 0.094 & \\
\hline 77 & 01/30/17 & $\mathrm{M}-12$ & 400 & 171 & 0 & 800 & 892.43 & 892.41 & 6.03 & 7.55 & 3.69E-09 & 0.009 & 0.011 & 1 & 1200 & 0.070 & \\
\hline 78 & $01 / 30 / 17$ & $\mathrm{M}-12$ & 400 & 175 & 0 & 850 & 892.41 & 892.38 & 8.48 & 10.48 & $5.45 \mathrm{E}-09$ & 0.011 & 0.015 & 1 & 1200 & 0.070 & \\
\hline 79 & $01 / 30 / 17$ & $\mathrm{M}-12$ & 400 & 171 & 0 & 900 & 892.38 & 892.32 & 11.47 & 13.62 & 8.11E-09 & 0.015 & 0.021 & 1 & 1200 & 0.070 & \\
\hline 80 & $01 / 30 / 17$ & $\mathrm{M}-12$ & 400 & 168 & 0 & 950 & 892.32 & 892.23 & 15.15 & 16.92 & $1.60 \mathrm{E}-08$ & 0.021 & 0.031 & 1 & 1200 & 0.070 & \\
\hline 81 & $01 / 30 / 17$ & $\mathrm{M}-12$ & 400 & 166 & 0 & 1000 & 892.23 & 891.88 & 18.00 & 19.82 & $6.02 \mathrm{E}-08$ & 0.031 & 0.071 & 1 & 1200 & 0.070 & \\
\hline 82 & 01/30/17 & $\mathrm{M}-12$ & 400 & 167 & 0 & 1050 & 891.88 & 890.94 & 21.35 & 22.77 & $2.06 \mathrm{E}-07$ & 0.071 & 0.176 & 1 & 1200 & 0.070 & \\
\hline 83 & $01 / 30 / 17$ & $\mathrm{M}-12$ & 400 & 162 & 0 & 1100 & 890.94 & 889.95 & 24.38 & 25.08 & $4.42 \mathrm{E}-07$ & 0.176 & 0.287 & 1 & 1200 & 0.070 & \\
\hline 84 & $02 / 01 / 17$ & $M-13$ & 400 & 383 & 0 & 800 & 897.55 & 897.52 & 5.53 & 7.82 & $3.78 \mathrm{E}-09$ & 0.000 & 0.003 & 1 & 1200 & 0.324 & \\
\hline 85 & $02 / 01 / 17$ & $M-13$ & 400 & 416 & 0 & 850 & 897.52 & 897.48 & 8.28 & 10.85 & 5.30E-09 & 0.003 & 0.008 & 1 & 1200 & 0.324 & \\
\hline 86 & $02 / 01 / 17$ & $\mathrm{M}-13$ & 400 & 454 & 0 & 900 & 897.48 & 897.44 & 11.55 & 13.07 & 7.94E-09 & 0.008 & 0.012 & 1 & 1200 & 0.324 & \\
\hline 87 & $02 / 01 / 17$ & $M-13$ & 400 & 442 & 0 & 950 & 897.44 & 897.28 & 14.55 & 16.65 & $2.27 \mathrm{E}-08$ & 0.012 & 0.030 & 1 & 1200 & 0.324 & \\
\hline 88 & $02 / 01 / 17$ & $\mathrm{M}-13$ & 400 & 398 & 0 & 1000 & 897.28 & 896.91 & 19.23 & 20.18 & $1.21 \mathrm{E}-07$ & 0.030 & 0.071 & 1 & 1200 & 0.324 & \\
\hline 89 & 02/01/17 & M-13 & 400 & 381 & 0 & 1050 & 896.91 & 895.63 & 22.85 & 23.33 & 8.29E-07 & 0.071 & 0.214 & 1 & 1200 & 0.324 & \\
\hline 90 & $02 / 01 / 17$ & $\mathrm{M}-13$ & 400 & 394 & 0 & 1100 & 895.63 & 890.99 & 23.58 & 25.27 & $8.51 \mathrm{E}-07$ & 0.214 & 0.731 & 1 & 1200 & 0.324 & \\
\hline 91 & $02 / 03 / 17$ & M-14 & 600 & 585 & 0 & 800 & 898.75 & 898.74 & 5.18 & 5.82 & $5.31 \mathrm{E}-09$ & 0.009 & 0.010 & 1 & 1200 & 0.130 & \\
\hline 92 & 02/03/17 & M-14 & 600 & 1060 & 0 & 850 & 898.74 & 898.71 & 8.82 & 10.00 & $6.81 \mathrm{E}-09$ & 0.010 & 0.013 & 1 & 1200 & 0.130 & \\
\hline 93 & $02 / 03 / 17$ & $\mathrm{M}-14$ & 600 & 1002 & 0 & 900 & 898.71 & 898.66 & 11.62 & 13.95 & $6.90 \mathrm{E}-09$ & 0.013 & 0.019 & 1 & 1200 & 0.130 & \\
\hline 94 & $02 / 03 / 17$ & $\mathrm{M}-14$ & 600 & 836 & 0 & 950 & 898.66 & 898.61 & 16.48 & 17.00 & $2.85 \mathrm{E}-08$ & 0.019 & 0.024 & 1 & 1200 & 0.130 & \\
\hline 95 & $02 / 03 / 17$ & $\mathrm{M}-14$ & 600 & 840 & 0 & 1000 & 898.61 & 898.19 & 18.93 & 19.68 & $1.73 \mathrm{E}-07$ & 0.024 & 0.071 & 1 & 1200 & 0.130 & \\
\hline 96 & $02 / 03 / 17$ & $\mathrm{M}-14$ & 600 & 837 & 0 & 1050 & 898.19 & 897.30 & 21.47 & 21.90 & $6.44 \mathrm{E}-07$ & 0.071 & 0.171 & 1 & 1200 & 0.130 & \\
\hline
\end{tabular}


ORNL/TM-2018/1057

\begin{tabular}{|c|c|c|c|c|c|c|c|c|c|c|c|c|c|c|c|c|c|}
\hline \multirow{3}{*}{$\begin{array}{l}\text { Data } \\
\text { No. }\end{array}$} & \multirow{3}{*}{ Test date } & \multirow{3}{*}{$\begin{array}{c}\text { Spec. } \\
\text { ID }\end{array}$} & \multicolumn{2}{|c|}{$\mathrm{P}_{\mathrm{H} 2 \mathrm{O}}$} & \multirow{2}{*}{$P_{\mathrm{H} 2}$} & \multirow{2}{*}{ Temp } & \multicolumn{2}{|c|}{ Weight } & \multicolumn{2}{|c|}{ Time in test } & \multirow[t]{2}{*}{ Rate } & \multicolumn{2}{|c|}{ Weight loss } & \multicolumn{3}{|c|}{ Preparation } & \multirow{2}{*}{ Notes } \\
\hline & & & target & actual & & & before & after & before & after & & before & after & time & temp & $\begin{array}{l}\text { wt. } \\
\text { loss }\end{array}$ & \\
\hline & & & $\mathrm{Pa}$ & $\mathrm{Pa}$ & $\mathrm{Pa}$ & ${ }^{\circ} \mathrm{C}$ & $\mathrm{mg}$ & $\mathrm{mg}$ & $\mathrm{h}$ & $\mathrm{h}$ & $s^{-1}$ & $\%$ & $\%$ & $\mathrm{~h}$ & ${ }^{\circ} \mathrm{C}$ & $\mathrm{mg}$ & \\
\hline 97 & $02 / 03 / 17$ & $M-14$ & 600 & 829 & 0 & 1100 & 897.30 & 895.39 & 24.67 & 25.02 & $1.69 \mathrm{E}-06$ & 0.171 & 0.383 & 1 & 1200 & 0.130 & \\
\hline 98 & $02 / 06 / 17$ & $M-15$ & 50 & 53 & 0 & 800 & 895.68 & 895.66 & 5.90 & 7.73 & $3.56 \mathrm{E}-09$ & 0.037 & 0.039 & 1 & 1200 & 0.120 & \\
\hline 99 & $02 / 06 / 17$ & $\mathrm{M}-15$ & 50 & 58 & 0 & 850 & 895.66 & 895.65 & 10.22 & 10.93 & 4.37E-09 & 0.039 & 0.041 & 1 & 1200 & 0.120 & \\
\hline 100 & $02 / 06 / 17$ & $\mathrm{M}-15$ & 50 & 58 & 0 & 900 & 895.65 & 895.61 & 11.48 & 13.20 & 7.03E-09 & 0.041 & 0.045 & 1 & 1200 & 0.120 & \\
\hline 101 & $02 / 06 / 17$ & $\mathrm{M}-15$ & 50 & 15 & 0 & 950 & 895.61 & 895.56 & 15.18 & 16.78 & 8.53E-09 & 0.045 & 0.050 & 1 & 1200 & 0.120 & \\
\hline 102 & 02/06/17 & M-15 & 50 & 15 & 0 & 1000 & 895.56 & 895.51 & 17.52 & 18.62 & $1.44 \mathrm{E}-08$ & 0.050 & 0.055 & 1 & 1200 & 0.120 & \\
\hline 103 & $02 / 06 / 17$ & $\mathrm{M}-15$ & 50 & 14 & 0 & 1050 & 895.51 & 895.45 & 20.62 & 21.42 & $2.52 \mathrm{E}-08$ & 0.055 & 0.063 & 1 & 1200 & 0.120 & \\
\hline 104 & 02/06/17 & $M-15$ & 50 & 14 & 0 & 1100 & 895.45 & 895.22 & 24.95 & 26.27 & $5.36 \mathrm{E}-08$ & 0.063 & 0.088 & 1 & 1200 & 0.120 & \\
\hline 105 & $02 / 08 / 17$ & $M-16$ & 150 & 149 & 0 & 800 & 833.43 & 833.41 & 5.67 & 7.64 & $3.38 \mathrm{E}-09$ & -0.045 & -0.042 & 1 & 1200 & -0.647 & \\
\hline 106 & 02/08/17 & M-16 & 150 & 157 & 0 & 850 & 833.41 & 833.38 & 8.73 & 10.37 & $6.71 \mathrm{E}-09$ & -0.042 & -0.039 & 1 & 1200 & -0.647 & \\
\hline 107 & $02 / 08 / 17$ & $M-16$ & 150 & 165 & 0 & 900 & 833.38 & 833.35 & 11.91 & 12.98 & $1.06 \mathrm{E}-08$ & -0.039 & -0.034 & 1 & 1200 & -0.647 & \\
\hline 108 & $02 / 08 / 17$ & $M-16$ & 150 & 167 & 0 & 950 & 833.35 & 833.23 & 14.67 & 16.52 & $2.16 \mathrm{E}-08$ & -0.034 & -0.020 & 1 & 1200 & -0.647 & \\
\hline 109 & $02 / 08 / 17$ & $M-16$ & 150 & 165 & 0 & 1000 & 833.23 & 832.73 & 18.19 & 19.94 & $9.54 \mathrm{E}-08$ & -0.020 & 0.040 & 1 & 1200 & -0.647 & \\
\hline 110 & $02 / 08 / 17$ & $M-16$ & 150 & 164 & 0 & 1050 & 832.73 & 832.03 & 22.27 & 23.08 & $2.85 \mathrm{E}-07$ & 0.040 & 0.123 & 1 & 1200 & -0.647 & \\
\hline 111 & $02 / 08 / 17$ & $M-16$ & 150 & 162 & 0 & 1100 & 832.03 & 830.05 & 24.54 & 25.73 & 5.57E-07 & 0.123 & 0.361 & 1 & 1200 & -0.647 & \\
\hline 112 & 02/09/17 & $M-17$ & 0 & 0 & 0 & 800 & 896.80 & 896.78 & 5.37 & 7.50 & 2.47E-09 & 0.021 & 0.023 & 1 & 1200 & 0.079 & \\
\hline 113 & $02 / 09 / 17$ & $\mathrm{M}-17$ & 0 & 0 & 0 & 850 & 896.78 & 896.76 & 8.53 & 10.50 & 4.56E-09 & 0.023 & 0.026 & 1 & 1200 & 0.079 & \\
\hline 114 & 02/09/17 & $\mathrm{M}-17$ & 0 & 0 & 0 & 900 & 896.76 & 896.73 & 12.17 & 13.68 & 5.74E-09 & 0.026 & 0.029 & 1 & 1200 & 0.079 & \\
\hline 115 & $02 / 09 / 17$ & $M-17$ & 0 & 0 & 0 & 950 & 896.73 & 896.69 & 15.05 & 16.87 & 5.96E-09 & 0.029 & 0.033 & 1 & 1200 & 0.079 & \\
\hline 116 & $02 / 09 / 17$ & $\mathrm{M}-17$ & 0 & 0 & 0 & 1000 & 896.69 & 896.66 & 18.62 & 19.83 & 8.19E-09 & 0.033 & 0.037 & 1 & 1200 & 0.079 & \\
\hline 117 & $02 / 09 / 17$ & $\mathrm{M}-17$ & 0 & 0 & 0 & 1050 & 896.66 & 896.61 & 21.60 & 23.08 & $1.11 \mathrm{E}-08$ & 0.037 & 0.043 & 1 & 1200 & 0.079 & \\
\hline 118 & 02/09/17 & $\mathrm{M}-17$ & 0 & 0 & 0 & 1100 & 896.61 & 896.54 & 24.78 & 26.08 & $1.72 \mathrm{E}-08$ & 0.043 & 0.051 & 1 & 1200 & 0.079 & \\
\hline 119 & $02 / 16 / 17$ & M-18 & 650 & 703 & 0 & 800 & 881.87 & 881.86 & 5.28 & 6.02 & $3.41 \mathrm{E}-09$ & 0.009 & 0.010 & 1 & 1200 & 0.078 & \\
\hline 120 & $02 / 16 / 17$ & $M-18$ & 650 & 1125 & 0 & 850 & 881.86 & 881.84 & 8.20 & 9.72 & 4.97E-09 & 0.010 & 0.013 & 1 & 1200 & 0.078 & \\
\hline 121 & $02 / 16 / 17$ & $\mathrm{M}-18$ & 650 & 1149 & 0 & 900 & 881.84 & 881.81 & 12.70 & 14.07 & 7.59E-09 & 0.013 & 0.016 & 1 & 1200 & 0.078 & \\
\hline 122 & $02 / 16 / 17$ & $\mathrm{M}-18$ & 650 & 1053 & 0 & 950 & 881.81 & 881.78 & 15.77 & 16.05 & $2.48 \mathrm{E}-08$ & 0.016 & 0.019 & 1 & 1200 & 0.078 & \\
\hline
\end{tabular}


ORNL/TM-2018/1057

\begin{tabular}{|c|c|c|c|c|c|c|c|c|c|c|c|c|c|c|c|c|c|}
\hline \multirow{3}{*}{$\begin{array}{l}\text { Data } \\
\text { No. }\end{array}$} & \multirow{3}{*}{ Test date } & \multirow{3}{*}{$\begin{array}{c}\text { Spec. } \\
\text { ID }\end{array}$} & \multicolumn{2}{|c|}{$\mathrm{P}_{\mathrm{H} 2 \mathrm{O}}$} & \multirow{2}{*}{$P_{\mathrm{H} 2}$} & \multirow{2}{*}{ Temp } & \multicolumn{2}{|c|}{ Weight } & \multicolumn{2}{|c|}{ Time in test } & \multirow[t]{2}{*}{ Rate } & \multicolumn{2}{|c|}{ Weight loss } & \multicolumn{3}{|c|}{ Preparation } & \multirow{2}{*}{ Notes } \\
\hline & & & target & actual & & & before & after & before & after & & before & after & time & temp & $\begin{array}{l}\text { wt. } \\
\text { loss }\end{array}$ & \\
\hline & & & $\mathrm{Pa}$ & $\mathrm{Pa}$ & $\mathrm{Pa}$ & ${ }^{\circ} \mathrm{C}$ & $\mathrm{mg}$ & $\mathrm{mg}$ & $\mathrm{h}$ & $\mathrm{h}$ & $\mathrm{s}^{-1}$ & $\%$ & $\%$ & $\mathrm{~h}$ & ${ }^{\circ} \mathrm{C}$ & $\mathrm{mg}$ & \\
\hline 123 & $02 / 16 / 17$ & $\mathrm{M}-18$ & 650 & 1231 & 0 & 1000 & 881.78 & 881.61 & 19.32 & 19.60 & $1.98 \mathrm{E}-07$ & 0.019 & 0.039 & 1 & 1200 & 0.078 & \\
\hline 124 & $02 / 16 / 17$ & $\mathrm{M}-18$ & 650 & 1111 & 0 & 1050 & 881.61 & 880.71 & 21.32 & 21.73 & $6.88 \mathrm{E}-07$ & 0.039 & 0.140 & 1 & 1200 & 0.078 & \\
\hline 125 & $02 / 16 / 17$ & $\mathrm{M}-18$ & 650 & 973 & 0 & 1100 & 880.71 & 879.79 & 24.10 & 24.27 & $1.71 \mathrm{E}-06$ & 0.140 & 0.245 & 1 & 1200 & 0.078 & \\
\hline 126 & $02 / 20 / 17$ & M-19 & 30 & 22 & 0 & 800 & 891.36 & 891.33 & 4.83 & 7.65 & $3.65 \mathrm{E}-09$ & -0.002 & 0.002 & 1 & 1200 & 0.073 & \\
\hline 127 & $02 / 20 / 17$ & M-19 & 30 & 19 & 0 & 850 & 891.33 & 891.28 & 8.57 & 10.82 & $6.09 \mathrm{E}-09$ & 0.002 & 0.007 & 1 & 1200 & 0.073 & \\
\hline 128 & $02 / 20 / 17$ & M-19 & 30 & 9 & 0 & 900 & 891.28 & 891.23 & 11.43 & 13.73 & 7.05E-09 & 0.007 & 0.012 & 1 & 1200 & 0.073 & \\
\hline 129 & $02 / 20 / 17$ & M-19 & 30 & 8 & 0 & 950 & 891.23 & 891.16 & 14.65 & 16.90 & $9.28 \mathrm{E}-09$ & 0.012 & 0.020 & 1 & 1200 & 0.073 & \\
\hline 130 & $02 / 20 / 17$ & M-19 & 30 & 8 & 0 & 1000 & 891.16 & 891.06 & 17.72 & 20.07 & $1.37 \mathrm{E}-08$ & 0.020 & 0.031 & 1 & 1200 & 0.073 & \\
\hline 131 & $02 / 20 / 17$ & M-19 & 30 & 9 & 0 & 1050 & 891.06 & 890.89 & 20.72 & 22.95 & $2.32 \mathrm{E}-08$ & 0.031 & 0.050 & 1 & 1200 & 0.073 & \\
\hline 132 & $02 / 20 / 17$ & M-19 & 30 & 9 & 0 & 1100 & 890.89 & 890.67 & 24.15 & 25.82 & $4.16 \mathrm{E}-08$ & 0.050 & 0.075 & 1 & 1200 & 0.073 & \\
\hline 133 & $02 / 23 / 17$ & $M-20$ & 80 & 76 & 0 & 800 & 891.48 & 891.42 & 5.08 & 7.63 & 7.45E-09 & 0.018 & 0.025 & 1 & 1200 & 0.181 & \\
\hline 134 & $02 / 23 / 17$ & $M-20$ & 80 & 76 & 0 & 850 & 891.42 & 891.35 & 8.43 & 10.82 & $9.13 E-09$ & 0.025 & 0.033 & 1 & 1200 & 0.181 & \\
\hline 135 & $02 / 23 / 17$ & $M-20$ & 80 & 77 & 0 & 900 & 891.35 & 891.24 & 11.52 & 13.75 & $1.52 \mathrm{E}-08$ & 0.033 & 0.045 & 1 & 1200 & 0.181 & \\
\hline 136 & $02 / 23 / 17$ & $M-20$ & 80 & 76 & 0 & 950 & 891.24 & 890.99 & 14.67 & 16.77 & $3.71 \mathrm{E}-08$ & 0.045 & 0.073 & 1 & 1200 & 0.181 & \\
\hline 137 & $02 / 23 / 17$ & $M-20$ & 80 & 76 & 0 & 1000 & 890.99 & 890.33 & 17.75 & 20.12 & 8.67E-08 & 0.073 & 0.147 & 1 & 1200 & 0.181 & \\
\hline 138 & $02 / 23 / 17$ & $M-20$ & 80 & 75 & 0 & 1050 & 890.33 & 889.14 & 20.87 & 23.10 & $1.67 \mathrm{E}-07$ & 0.147 & 0.281 & 1 & 1200 & 0.181 & \\
\hline 139 & $02 / 23 / 17$ & $M-20$ & 80 & 76 & 0 & 1100 & 889.14 & 886.79 & 23.97 & 26.17 & $3.34 \mathrm{E}-07$ & 0.281 & 0.544 & 1 & 1200 & 0.181 & \\
\hline 140 & $02 / 24 / 17$ & $M-21$ & 0 & 0 & 0 & 800 & 897.87 & 897.84 & 4.62 & 7.32 & $3.21 \mathrm{E}-09$ & 0.002 & 0.006 & 1 & 1200 & 0.087 & \\
\hline 141 & $02 / 24 / 17$ & $M-21$ & 0 & 0 & 0 & 850 & 897.84 & 897.80 & 8.33 & 10.62 & $5.40 \mathrm{E}-09$ & 0.006 & 0.010 & 1 & 1200 & 0.087 & \\
\hline 142 & $02 / 24 / 17$ & $M-21$ & 0 & 0 & 0 & 900 & 897.80 & 897.77 & 11.65 & 12.97 & $6.09 \mathrm{E}-09$ & 0.010 & 0.013 & 1 & 1200 & 0.087 & \\
\hline 143 & $02 / 24 / 17$ & $M-21$ & 0 & 0 & 0 & 950 & 897.77 & 897.75 & 16.13 & 17.12 & $6.25 \mathrm{E}-09$ & 0.013 & 0.015 & 1 & 1200 & 0.087 & \\
\hline 144 & $02 / 24 / 17$ & $M-21$ & 0 & 0 & 0 & 1000 & 897.75 & 897.70 & 17.88 & 19.88 & 7.74E-09 & 0.015 & 0.021 & 1 & 1200 & 0.087 & \\
\hline 145 & $02 / 24 / 17$ & $M-21$ & 0 & 0 & 0 & 1050 & 897.70 & 897.63 & 20.87 & 22.98 & $1.09 \mathrm{E}-08$ & 0.021 & 0.029 & 1 & 1200 & 0.087 & \\
\hline 146 & $02 / 24 / 17$ & $M-21$ & 0 & 0 & 0 & 1100 & 897.63 & 897.51 & 23.90 & 26.10 & $1.65 \mathrm{E}-08$ & 0.029 & 0.042 & 1 & 1200 & 0.087 & \\
\hline 147 & $02 / 27 / 17$ & $M-22$ & 700 & 670 & 0 & 800 & 895.84 & 895.83 & 6.32 & 7.15 & $5.60 \mathrm{E}-09$ & -0.001 & 0.000 & 1 & 1200 & 0.015 & \\
\hline 148 & $02 / 27 / 17$ & $M-22$ & 700 & 968 & 0 & 850 & 895.83 & 895.82 & 8.27 & 8.67 & $1.55 \mathrm{E}-09$ & 0.000 & 0.001 & 1 & 1200 & 0.015 & \\
\hline
\end{tabular}


ORNL/TM-2018/1057

\begin{tabular}{|c|c|c|c|c|c|c|c|c|c|c|c|c|c|c|c|c|c|}
\hline \multirow{3}{*}{$\begin{array}{l}\text { Data } \\
\text { No. }\end{array}$} & \multirow{3}{*}{ Test date } & \multirow{3}{*}{$\begin{array}{c}\text { Spec. } \\
\text { ID }\end{array}$} & \multicolumn{2}{|c|}{$\mathrm{P}_{\mathrm{H} 2 \mathrm{O}}$} & \multirow{2}{*}{$P_{\mathrm{H} 2}$} & \multirow{2}{*}{ Temp } & \multicolumn{2}{|c|}{ Weight } & \multicolumn{2}{|c|}{ Time in test } & \multirow[t]{2}{*}{ Rate } & \multicolumn{2}{|c|}{ Weight loss } & \multicolumn{3}{|c|}{ Preparation } & \multirow{2}{*}{ Notes } \\
\hline & & & target & actual & & & before & after & before & after & & before & after & time & temp & $\begin{array}{l}\text { wt. } \\
\text { loss }\end{array}$ & \\
\hline & & & $\mathrm{Pa}$ & $\mathrm{Pa}$ & $\mathrm{Pa}$ & ${ }^{\circ} \mathrm{C}$ & $\mathrm{mg}$ & $\mathrm{mg}$ & $\mathrm{h}$ & $\mathrm{h}$ & $\mathrm{s}^{-1}$ & $\%$ & $\%$ & $\mathrm{~h}$ & ${ }^{\circ} \mathrm{C}$ & $\mathrm{mg}$ & \\
\hline 149 & $02 / 27 / 17$ & $M-22$ & 700 & 1033 & 0 & 900 & 895.82 & 895.81 & 11.87 & 12.67 & $5.81 \mathrm{E}-09$ & 0.001 & 0.002 & 1 & 1200 & 0.015 & \\
\hline 150 & $02 / 27 / 17$ & $M-22$ & 700 & 986 & 0 & 950 & 895.81 & 895.76 & 14.35 & 15.10 & $1.94 \mathrm{E}-08$ & 0.002 & 0.008 & 1 & 1200 & 0.015 & \\
\hline 151 & $02 / 27 / 17$ & $M-22$ & 700 & 977 & 0 & 1000 & 895.76 & 894.92 & 17.52 & 19.28 & $1.48 \mathrm{E}-07$ & 0.008 & 0.101 & 1 & 1200 & 0.015 & \\
\hline 152 & $02 / 27 / 17$ & $M-22$ & 700 & 983 & 0 & 1050 & 894.92 & 892.91 & 21.07 & 22.02 & $6.57 \mathrm{E}-07$ & 0.101 & 0.326 & 1 & 1200 & 0.015 & \\
\hline 153 & $02 / 27 / 17$ & $M-22$ & 700 & 899 & 0 & 1100 & 892.91 & 886.03 & 23.78 & 25.08 & $1.65 \mathrm{E}-06$ & 0.326 & 1.094 & 1 & 1200 & 0.015 & \\
\hline 154 & $02 / 28 / 17$ & $M-23$ & 35 & 3 & 0 & 800 & 890.59 & 890.56 & 5.00 & 7.40 & 4.03E-09 & 0.012 & 0.015 & 1 & 1200 & 0.115 & \\
\hline 155 & $02 / 28 / 17$ & $M-23$ & 35 & 4 & 0 & 850 & 890.56 & 890.52 & 8.52 & 10.62 & 4.60E-09 & 0.015 & 0.019 & 1 & 1200 & 0.115 & \\
\hline 156 & $02 / 28 / 17$ & $M-23$ & 35 & 4 & 0 & 900 & 890.52 & 890.49 & 11.68 & 13.68 & $4.83 \mathrm{E}-09$ & 0.019 & 0.022 & 1 & 1200 & 0.115 & \\
\hline 157 & 03/01/17 & $M-24$ & 35 & 30 & 0 & 800 & 897.99 & 897.98 & 6.17 & 7.82 & $2.44 \mathrm{E}-09$ & 0.007 & 0.008 & 1 & 1200 & 0.050 & \\
\hline 158 & 03/01/17 & $M-24$ & 35 & 31 & 0 & 850 & 897.98 & 897.96 & 8.55 & 9.60 & 4.12E-09 & 0.008 & 0.010 & 1 & 1200 & 0.050 & \\
\hline 159 & 03/01/17 & $M-24$ & 35 & 31 & 0 & 900 & 897.96 & 897.95 & 12.00 & 12.82 & 4.15E-09 & 0.010 & 0.011 & 1 & 1200 & 0.050 & \\
\hline 160 & 03/01/17 & $M-24$ & 35 & 30 & 0 & 950 & 897.95 & 897.92 & 14.88 & 16.48 & 5.99E-09 & 0.011 & 0.014 & 1 & 1200 & 0.050 & \\
\hline 161 & 03/01/17 & $M-24$ & 35 & 30 & 0 & 1000 & 897.92 & 897.85 & 18.03 & 19.67 & $1.34 \mathrm{E}-08$ & 0.014 & 0.022 & 1 & 1200 & 0.050 & \\
\hline 162 & 03/01/17 & $M-24$ & 35 & 31 & 0 & 1050 & 897.85 & 897.74 & 22.15 & 23.10 & $3.75 \mathrm{E}-08$ & 0.022 & 0.035 & 1 & 1200 & 0.050 & \\
\hline 163 & $03 / 01 / 17$ & $\mathrm{M}-24$ & 35 & 29 & 0 & 1100 & 897.74 & 897.37 & 24.53 & 25.75 & $9.33 \mathrm{E}-08$ & 0.035 & 0.076 & 1 & 1200 & 0.050 & \\
\hline 164 & 03/08/17 & $M-25$ & 300 & 302 & 12 & 800 & 903.05 & 903.05 & 5.88 & 6.58 & 2.20E-09 & 0.003 & 0.003 & 1 & 1200 & 0.028 & \\
\hline 165 & 03/08/17 & $M-25$ & 300 & 305 & 12 & 850 & 903.05 & 903.04 & 8.37 & 9.23 & $1.79 \mathrm{E}-09$ & 0.003 & 0.004 & 1 & 1200 & 0.028 & \\
\hline 166 & 03/08/17 & $M-25$ & 300 & 330 & 12 & 900 & 903.04 & 903.02 & 11.77 & 13.80 & $3.18 \mathrm{E}-09$ & 0.004 & 0.006 & 1 & 1200 & 0.028 & \\
\hline 167 & 03/08/17 & $M-25$ & 300 & 349 & 12 & 950 & 903.02 & 902.92 & 14.78 & 16.88 & $1.54 \mathrm{E}-08$ & 0.006 & 0.018 & 1 & 1200 & 0.028 & \\
\hline 168 & $03 / 08 / 17$ & $M-25$ & 300 & 368 & 12 & 1000 & 902.92 & 902.69 & 17.70 & 18.67 & $7.23 \mathrm{E}-08$ & 0.018 & 0.043 & 1 & 1200 & 0.028 & \\
\hline 169 & 03/08/17 & $M-25$ & 300 & 388 & 12 & 1050 & 902.69 & 902.21 & 21.38 & 21.80 & $3.51 \mathrm{E}-07$ & 0.043 & 0.096 & 1 & 1200 & 0.028 & \\
\hline 170 & 03/08/17 & $M-25$ & 300 & 329 & 12 & 1100 & 902.21 & 898.69 & 24.12 & 25.50 & $7.85 \mathrm{E}-07$ & 0.096 & 0.486 & 1 & 1200 & 0.028 & \\
\hline 171 & 03/09/17 & M-26 & 100 & 125 & 25 & 800 & 890.16 & 890.16 & 6.32 & 7.17 & 1.10E-09 & -0.361 & -0.361 & 1 & 1200 & 0.028 & \\
\hline 172 & 03/09/17 & $M-26$ & 100 & 267 & 25 & 850 & 890.16 & 890.16 & 10.17 & 10.78 & $2.56 \mathrm{E}-09$ & -0.361 & -0.360 & 1 & 1200 & 0.028 & \\
\hline 173 & 03/09/17 & $M-26$ & 100 & 131 & 25 & 900 & 890.16 & 890.15 & 13.22 & 13.92 & $8.92 \mathrm{E}-10$ & -0.360 & -0.360 & 1 & 1200 & 0.028 & \\
\hline 174 & 03/09/17 & $M-26$ & 100 & 127 & 25 & 950 & 890.15 & 890.13 & 14.75 & 16.62 & 3.17E-09 & -0.360 & -0.358 & 1 & 1200 & 0.028 & \\
\hline
\end{tabular}


ORNL/TM-2018/1057

\begin{tabular}{|c|c|c|c|c|c|c|c|c|c|c|c|c|c|c|c|c|c|}
\hline \multirow{3}{*}{$\begin{array}{l}\text { Data } \\
\text { No. }\end{array}$} & \multirow{3}{*}{ Test date } & \multirow{3}{*}{$\begin{array}{c}\text { Spec. } \\
\text { ID }\end{array}$} & \multicolumn{2}{|c|}{$\mathrm{P}_{\mathrm{H} 2 \mathrm{O}}$} & \multirow{2}{*}{$\mathrm{P}_{\mathrm{H} 2}$} & \multirow{2}{*}{ Temp } & \multicolumn{2}{|c|}{ Weight } & \multicolumn{2}{|c|}{ Time in test } & \multirow[t]{2}{*}{ Rate } & \multicolumn{2}{|c|}{ Weight loss } & \multicolumn{3}{|c|}{ Preparation } & \multirow{2}{*}{ Notes } \\
\hline & & & target & actual & & & before & after & before & after & & before & after & time & temp & $\begin{array}{l}\text { wt. } \\
\text { loss }\end{array}$ & \\
\hline & & & $\mathrm{Pa}$ & $\mathrm{Pa}$ & $\mathrm{Pa}$ & ${ }^{\circ} \mathrm{C}$ & $\mathrm{mg}$ & $\mathrm{mg}$ & $\mathrm{h}$ & $\mathrm{h}$ & $\mathrm{s}^{-1}$ & $\%$ & $\%$ & $\mathrm{~h}$ & ${ }^{\circ} \mathrm{C}$ & $\mathrm{mg}$ & \\
\hline 175 & 03/09/17 & $M-26$ & 100 & 119 & 25 & 1000 & 890.13 & 890.05 & 17.77 & 19.37 & $1.70 \mathrm{E}-08$ & -0.358 & -0.348 & 1 & 1200 & 0.028 & \\
\hline 176 & 03/09/17 & $M-26$ & 100 & 117 & 25 & 1050 & 890.05 & 889.75 & 21.58 & 22.88 & $7.23 \mathrm{E}-08$ & -0.348 & -0.314 & 1 & 1200 & 0.028 & \\
\hline 177 & 03/09/17 & $M-26$ & 100 & 119 & 25 & 1100 & 889.75 & 888.19 & 24.40 & 26.05 & $2.95 \mathrm{E}-07$ & -0.314 & -0.139 & 1 & 1200 & 0.028 & \\
\hline 178 & $03 / 13 / 17$ & $M-27$ & 50 & 49 & 38 & 800 & 890.16 & 890.16 & 5.20 & 7.30 & $1.93 \mathrm{E}-09$ & 0.209 & 0.210 & 1 & 1200 & 0.028 & \\
\hline 179 & $03 / 13 / 17$ & $M-27$ & 50 & 44 & 36 & 850 & 890.16 & 890.16 & 8.63 & 10.18 & $1.61 \mathrm{E}-09$ & 0.210 & 0.210 & 1 & 1200 & 0.028 & \\
\hline 180 & $03 / 13 / 17$ & $M-27$ & 50 & 24 & 38 & 900 & 890.16 & 890.15 & 12.42 & 13.57 & $-2.71 \mathrm{E}-10$ & 0.210 & 0.210 & 1 & 1200 & 0.028 & $\mathrm{R}$ \\
\hline 181 & $03 / 13 / 17$ & $M-27$ & 50 & 22 & 36 & 950 & 890.15 & 890.13 & 15.03 & 16.90 & $5.01 \mathrm{E}-10$ & 0.210 & 0.213 & 1 & 1200 & 0.028 & \\
\hline 182 & $03 / 13 / 17$ & $M-27$ & 50 & 22 & 37 & 1000 & 890.13 & 890.05 & 17.87 & 19.82 & $2.24 \mathrm{E}-09$ & 0.213 & 0.222 & 1 & 1200 & 0.028 & \\
\hline 183 & $03 / 13 / 17$ & $M-27$ & 50 & 22 & 37 & 1050 & 890.05 & 889.75 & 20.97 & 22.85 & $6.14 \mathrm{E}-09$ & 0.222 & 0.256 & 1 & 1200 & 0.028 & \\
\hline 184 & $03 / 13 / 17$ & $M-27$ & 50 & 22 & 38 & 1100 & 889.75 & 888.19 & 23.85 & 26.23 & $1.47 \mathrm{E}-08$ & 0.256 & 0.431 & 1 & 1200 & 0.028 & \\
\hline 185 & $03 / 14 / 17$ & $M-28$ & 20 & 23 & 100 & 800 & 892.09 & 892.09 & 5.90 & 7.68 & $2.20 \mathrm{E}-09$ & -0.080 & -0.079 & 1 & 1200 & 0.028 & UR \\
\hline 186 & $03 / 14 / 17$ & $M-28$ & 20 & 23 & 100 & 850 & 892.09 & 892.09 & 8.52 & 10.80 & 1.79E-09 & -0.079 & -0.079 & 1 & 1200 & 0.028 & UR \\
\hline 187 & $03 / 14 / 17$ & $M-28$ & 20 & 23 & 100 & 900 & 892.09 & 892.08 & 11.47 & 13.73 & $3.18 \mathrm{E}-09$ & -0.079 & -0.079 & 1 & 1200 & 0.028 & UR \\
\hline 188 & $03 / 14 / 17$ & $M-28$ & 20 & 23 & 100 & 950 & 892.08 & 892.08 & 14.80 & 17.00 & $1.54 \mathrm{E}-08$ & -0.079 & -0.079 & 1 & 1200 & 0.028 & UR \\
\hline 189 & $03 / 14 / 17$ & $M-28$ & 20 & 23 & 100 & 1000 & 892.08 & 892.06 & 17.72 & 19.90 & $7.23 \mathrm{E}-08$ & -0.079 & -0.077 & 1 & 1200 & 0.028 & UR \\
\hline 190 & $03 / 14 / 17$ & $M-28$ & 20 & 23 & 100 & 1050 & 892.06 & 891.99 & 20.68 & 23.08 & $3.51 \mathrm{E}-07$ & -0.077 & -0.068 & 1 & 1200 & 0.028 & UR \\
\hline 191 & $03 / 14 / 17$ & $M-28$ & 20 & 23 & 100 & 1100 & 891.99 & 891.83 & 23.67 & 25.97 & $7.85 \mathrm{E}-07$ & -0.068 & -0.051 & 1 & 1200 & 0.028 & UR \\
\hline 192 & $03 / 16 / 17$ & $M-29$ & 3 & 3 & 46 & 800 & 899.57 & 899.54 & 4.84 & 7.24 & $2.20 \mathrm{E}-09$ & -1.122 & -1.119 & 1 & 1200 & 0.028 & UR \\
\hline 193 & $03 / 16 / 17$ & $M-29$ & 3 & 3 & 46 & 850 & 899.54 & 899.50 & 7.68 & 10.49 & 1.79E-09 & -1.119 & -1.114 & 1 & 1200 & 0.028 & UR \\
\hline 194 & $03 / 16 / 17$ & $M-29$ & 3 & 3 & 46 & 900 & 899.50 & 899.44 & 10.83 & 13.43 & $3.18 \mathrm{E}-09$ & -1.114 & -1.107 & 1 & 1200 & 0.028 & UR \\
\hline 195 & $03 / 16 / 17$ & $M-29$ & 3 & 3 & 46 & 950 & 899.44 & 899.32 & 13.89 & 16.55 & $1.54 \mathrm{E}-08$ & -1.107 & -1.093 & 1 & 1200 & 0.028 & UR \\
\hline 196 & $03 / 16 / 17$ & $M-29$ & 3 & 3 & 46 & 1000 & 899.32 & 898.94 & 17.05 & 19.68 & $7.23 \mathrm{E}-08$ & -1.093 & -1.050 & 1 & 1200 & 0.028 & UR \\
\hline 197 & $03 / 16 / 17$ & $M-29$ & 3 & 3 & 46 & 1050 & 898.94 & 897.73 & 20.14 & 22.64 & $3.51 \mathrm{E}-07$ & -1.050 & -0.915 & 1 & 1200 & 0.028 & UR \\
\hline 198 & $03 / 16 / 17$ & $M-29$ & 3 & 3 & 46 & 1100 & 897.73 & 894.59 & 23.11 & 25.83 & $7.85 \mathrm{E}-07$ & -0.915 & -0.562 & 1 & 1200 & 0.028 & UR \\
\hline 199 & $03 / 20 / 17$ & $M-30$ & 300 & 294 & 25 & 800 & 896.72 & 896.71 & 6.10 & 7.52 & $1.53 \mathrm{E}-09$ & 0.037 & 0.038 & 1 & 1200 & 0.059 & \\
\hline 200 & $03 / 20 / 17$ & $M-30$ & 300 & 296 & 25 & 850 & 896.71 & 896.71 & 8.27 & 10.43 & 8.60E-10 & 0.038 & 0.038 & 1 & 1200 & 0.059 & \\
\hline
\end{tabular}


ORNL/TM-2018/1057

\begin{tabular}{|c|c|c|c|c|c|c|c|c|c|c|c|c|c|c|c|c|c|}
\hline \multirow{3}{*}{$\begin{array}{l}\text { Data } \\
\text { No. }\end{array}$} & \multirow{3}{*}{ Test date } & \multirow{3}{*}{$\begin{array}{c}\text { Spec. } \\
\text { ID }\end{array}$} & \multicolumn{2}{|c|}{$\mathrm{P}_{\mathrm{H} 2 \mathrm{O}}$} & \multirow{2}{*}{$\mathrm{P}_{\mathrm{H} 2}$} & \multirow{2}{*}{ Temp } & \multicolumn{2}{|c|}{ Weight } & \multicolumn{2}{|c|}{ Time in test } & \multirow[t]{2}{*}{ Rate } & \multicolumn{2}{|c|}{ Weight loss } & \multicolumn{3}{|c|}{ Preparation } & \multirow{2}{*}{ Notes } \\
\hline & & & target & actual & & & before & after & before & after & & before & after & time & temp & $\begin{array}{l}\text { wt. } \\
\text { loss }\end{array}$ & \\
\hline & & & $\mathrm{Pa}$ & $\mathrm{Pa}$ & $\mathrm{Pa}$ & ${ }^{\circ} \mathrm{C}$ & $\mathrm{mg}$ & $\mathrm{mg}$ & $\mathrm{h}$ & $\mathrm{h}$ & $\mathrm{s}^{-1}$ & $\%$ & $\%$ & $\mathrm{~h}$ & ${ }^{\circ} \mathrm{C}$ & $\mathrm{mg}$ & \\
\hline 201 & $03 / 20 / 17$ & $M-30$ & 300 & 315 & 25 & 900 & 896.71 & 896.70 & 11.43 & 13.27 & $1.52 \mathrm{E}-09$ & 0.038 & 0.039 & 1 & 1200 & 0.059 & \\
\hline 202 & $03 / 20 / 17$ & $M-30$ & 300 & 327 & 25 & 950 & 896.70 & 896.67 & 14.93 & 16.60 & 5.75E-09 & 0.039 & 0.043 & 1 & 1200 & 0.059 & \\
\hline 203 & $03 / 20 / 17$ & $M-30$ & 300 & 341 & 25 & 1000 & 896.67 & 896.45 & 17.77 & 19.73 & $3.40 \mathrm{E}-08$ & 0.043 & 0.067 & 1 & 1200 & 0.059 & \\
\hline 204 & $03 / 20 / 17$ & $M-30$ & 300 & 325 & 25 & 1050 & 896.45 & 895.49 & 21.62 & 23.10 & $2.01 \mathrm{E}-07$ & 0.067 & 0.173 & 1 & 1200 & 0.059 & \\
\hline 205 & $03 / 20 / 17$ & $M-30$ & 300 & 311 & 25 & 1100 & 895.49 & 894.08 & 25.37 & 26.15 & $5.64 \mathrm{E}-07$ & 0.173 & 0.332 & 1 & 1200 & 0.059 & \\
\hline 206 & $03 / 21 / 17$ & M-31 & 100 & 169 & 39 & 800 & 903.72 & 903.71 & 5.52 & 7.62 & 4.39E-10 & 0.010 & 0.011 & 1 & 1200 & 0.082 & \\
\hline 207 & $03 / 21 / 17$ & M-31 & 100 & 171 & 39 & 850 & 903.71 & 903.71 & 9.52 & 10.73 & $2.54 \mathrm{E}-10$ & 0.011 & 0.011 & 1 & 1200 & 0.082 & \\
\hline 208 & $03 / 21 / 17$ & M-31 & 100 & 172 & 39 & 900 & 903.71 & 903.71 & 11.62 & 13.47 & $1.66 \mathrm{E}-10$ & 0.011 & 0.011 & 1 & 1200 & 0.082 & \\
\hline 209 & $03 / 21 / 17$ & M-31 & 100 & 167 & 39 & 950 & 903.71 & 903.70 & 14.98 & 16.87 & 1.79E-09 & 0.011 & 0.012 & 1 & 1200 & 0.082 & \\
\hline 210 & $03 / 21 / 17$ & M-31 & 100 & 152 & 39 & 1000 & 903.70 & 903.65 & 17.95 & 19.83 & 8.99E-09 & 0.012 & 0.018 & 1 & 1200 & 0.082 & \\
\hline 211 & $03 / 21 / 17$ & $M-31$ & 100 & 165 & 39 & 1050 & 903.65 & 903.40 & 21.80 & 23.15 & $5.62 \mathrm{E}-08$ & 0.018 & 0.045 & 1 & 1200 & 0.082 & \\
\hline 212 & $03 / 21 / 17$ & M-31 & 100 & 153 & 39 & 1100 & 903.40 & 902.60 & 24.73 & 26.03 & $1.88 \mathrm{E}-07$ & 0.045 & 0.134 & 1 & 1200 & 0.082 & \\
\hline 213 & $03 / 23 / 17$ & $M-32$ & 50 & 62 & 100 & 800 & 893.92 & 893.91 & 5.10 & 7.48 & $1.04 \mathrm{E}-09$ & 0.005 & 0.006 & 1 & 1200 & 0.050 & \\
\hline 214 & $03 / 23 / 17$ & $M-32$ & 50 & 68 & 100 & 850 & 893.91 & 893.92 & 8.57 & 10.68 & $-4.42 \mathrm{E}-10$ & 0.006 & 0.006 & 1 & 1200 & 0.050 & $\mathrm{R}$ \\
\hline 215 & $03 / 23 / 17$ & $M-32$ & 50 & 59 & 100 & 900 & 893.92 & 893.92 & 11.98 & 13.87 & $-1.64 \mathrm{E}-10$ & 0.006 & 0.006 & 1 & 1200 & 0.050 & $\mathrm{R}$ \\
\hline 216 & $03 / 23 / 17$ & $M-32$ & 50 & 33 & 100 & 950 & 893.92 & 893.92 & 14.65 & 16.85 & $2.82 \mathrm{E}-10$ & 0.006 & 0.006 & 1 & 1200 & 0.050 & \\
\hline 217 & $03 / 23 / 17$ & $M-32$ & 50 & 31 & 100 & 1000 & 893.92 & 893.91 & 17.93 & 20.07 & 1.31E-09 & 0.006 & 0.007 & 1 & 1200 & 0.050 & \\
\hline 218 & $03 / 23 / 17$ & $M-32$ & 50 & 31 & 100 & 1050 & 893.91 & 893.87 & 20.83 & 22.97 & 5.52E-09 & 0.007 & 0.011 & 1 & 1200 & 0.050 & \\
\hline 219 & $03 / 23 / 17$ & $M-32$ & 50 & 31 & 100 & 1100 & 893.87 & 893.80 & 23.92 & 25.55 & $1.30 \mathrm{E}-08$ & 0.011 & 0.019 & 1 & 1200 & 0.050 & \\
\hline 220 & $03 / 24 / 17$ & M-33 & 3 & 3 & 11 & 800 & 899.50 & 899.50 & 5.75 & 7.62 & $8.26 \mathrm{E}-10$ & 0.004 & 0.005 & 1 & 1200 & 0.042 & \\
\hline 221 & $03 / 24 / 17$ & M-33 & 3 & 3 & 11 & 850 & 899.50 & 899.49 & 8.53 & 10.72 & 1.27E-09 & 0.005 & 0.006 & 1 & 1200 & 0.042 & \\
\hline 222 & $03 / 24 / 17$ & M-33 & 3 & 4 & 11 & 900 & 899.49 & 899.49 & 11.78 & 13.68 & $-1.63 \mathrm{E}-10$ & 0.006 & 0.006 & 1 & 1200 & 0.042 & $\mathrm{R}$ \\
\hline 223 & $03 / 24 / 17$ & M-33 & 3 & 4 & 11 & 950 & 899.49 & 899.49 & 15.50 & 16.95 & $6.39 \mathrm{E}-10$ & 0.006 & 0.006 & 1 & 1200 & 0.042 & \\
\hline 224 & $03 / 24 / 17$ & M-33 & 3 & 4 & 11 & 1000 & 899.49 & 899.48 & 17.93 & 19.95 & $6.12 \mathrm{E}-10$ & 0.006 & 0.007 & 1 & 1200 & 0.042 & \\
\hline 225 & $03 / 24 / 17$ & M-33 & 3 & 4 & 11 & 1050 & 899.48 & 899.47 & 20.93 & 23.03 & $1.18 \mathrm{E}-09$ & 0.007 & 0.007 & 1 & 1200 & 0.042 & \\
\hline 226 & $03 / 24 / 17$ & $M-33$ & 3 & 3 & 10 & 1100 & 899.47 & 899.47 & 23.75 & 26.12 & $1.04 \mathrm{E}-09$ & 0.007 & 0.008 & 1 & 1200 & 0.042 & \\
\hline
\end{tabular}


ORNL/TM-2018/1057

\begin{tabular}{|c|c|c|c|c|c|c|c|c|c|c|c|c|c|c|c|c|c|}
\hline \multirow{3}{*}{$\begin{array}{l}\text { Data } \\
\text { No. }\end{array}$} & \multirow{3}{*}{ Test date } & \multirow{3}{*}{$\begin{array}{c}\text { Spec. } \\
\text { ID }\end{array}$} & \multicolumn{2}{|c|}{$\mathrm{P}_{\mathrm{H} 2 \mathrm{O}}$} & \multirow{2}{*}{$P_{\mathrm{H} 2}$} & \multirow{2}{*}{ Temp } & \multicolumn{2}{|c|}{ Weight } & \multicolumn{2}{|c|}{ Time in test } & \multirow[t]{2}{*}{ Rate } & \multicolumn{2}{|c|}{ Weight loss } & \multicolumn{3}{|c|}{ Preparation } & \multirow{2}{*}{ Notes } \\
\hline & & & target & actual & & & before & after & before & after & & before & after & time & temp & $\begin{array}{l}\text { wt. } \\
\text { loss }\end{array}$ & \\
\hline & & & $\mathrm{Pa}$ & $\mathrm{Pa}$ & $\mathrm{Pa}$ & ${ }^{\circ} \mathrm{C}$ & $\mathrm{mg}$ & $\mathrm{mg}$ & $\mathrm{h}$ & $\mathrm{h}$ & $\mathrm{s}^{-1}$ & $\%$ & $\%$ & $\mathrm{~h}$ & ${ }^{\circ} \mathrm{C}$ & $\mathrm{mg}$ & \\
\hline 227 & $04 / 27 / 17$ & $M-34$ & 20 & 3 & 13 & 800 & 892.09 & 892.08 & 6.05 & 7.65 & $9.73 \mathrm{E}-10$ & 0.000 & 0.001 & 1 & 1200 & 0.275 & \\
\hline 228 & $04 / 27 / 17$ & $M-34$ & 20 & 3 & 13 & 850 & 892.08 & 892.08 & 8.50 & 10.82 & $1.34 \mathrm{E}-10$ & 0.001 & 0.001 & 1 & 1200 & 0.275 & \\
\hline 229 & $04 / 27 / 17$ & $M-34$ & 20 & 4 & 13 & 900 & 892.08 & 892.08 & 11.88 & 13.82 & $-1.61 \mathrm{E}-10$ & 0.001 & 0.001 & 1 & 1200 & 0.275 & $\mathrm{R}$ \\
\hline 230 & $04 / 27 / 17$ & $M-34$ & 20 & 4 & 13 & 950 & 892.08 & 892.08 & 15.08 & 17.05 & $9.48 \mathrm{E}-10$ & 0.001 & 0.001 & 1 & 1200 & 0.275 & \\
\hline 231 & $04 / 27 / 17$ & $M-34$ & 20 & 4 & 13 & 1000 & 892.08 & 892.07 & 18.82 & 20.08 & $2.22 \mathrm{E}-09$ & 0.001 & 0.002 & 1 & 1200 & 0.275 & \\
\hline 232 & $04 / 27 / 17$ & $M-34$ & 20 & 4 & 13 & 1050 & 892.07 & 892.04 & 21.38 & 22.93 & 4.82E-09 & 0.002 & 0.005 & 1 & 1200 & 0.275 & \\
\hline 233 & $04 / 27 / 17$ & $M-34$ & 20 & 4 & 13 & 1100 & 892.04 & 891.99 & 24.02 & 25.97 & $9.26 \mathrm{E}-09$ & 0.005 & 0.011 & 1 & 1200 & 0.275 & \\
\hline 234 & $05 / 03 / 17$ & $M-35$ & 20 & 4 & 14 & 800 & 894.36 & 894.35 & 6.70 & 7.95 & 1.49E-09 & 0.000 & 0.001 & 1 & 1200 & 0.282 & \\
\hline 235 & $05 / 03 / 17$ & M-35 & 20 & 4 & 14 & 850 & 894.35 & 894.35 & 9.88 & 10.83 & 1.63E-09 & 0.001 & 0.001 & 1 & 1200 & 0.282 & \\
\hline 236 & 05/03/17 & $M-35$ & 20 & 4 & 14 & 900 & 894.35 & 894.35 & 12.08 & 13.85 & $0.00 \mathrm{E}+00$ & 0.001 & 0.001 & 1 & 1200 & 0.282 & $\mathrm{R}$ \\
\hline 237 & 05/03/17 & $M-35$ & 20 & 4 & 14 & 950 & 894.35 & 894.34 & 15.27 & 17.13 & $5.01 \mathrm{E}-10$ & 0.001 & 0.002 & 1 & 1200 & 0.282 & \\
\hline 238 & 05/03/17 & M-35 & 20 & 4 & 14 & 1000 & 894.34 & 894.34 & 17.73 & 19.23 & $1.24 \mathrm{E}-09$ & 0.002 & 0.002 & 1 & 1200 & 0.282 & \\
\hline 239 & $05 / 03 / 17$ & M-35 & 20 & 3 & 14 & 1050 & 894.34 & 894.32 & 20.80 & 22.70 & 2.94E-09 & 0.002 & 0.004 & 1 & 1200 & 0.282 & \\
\hline 240 & $05 / 03 / 17$ & M-35 & 20 & 3 & 14 & 1100 & 894.32 & 894.29 & 24.02 & 25.93 & 4.39E-09 & 0.004 & 0.007 & 1 & 1200 & 0.282 & \\
\hline 241 & $05 / 04 / 17$ & $M-36$ & 300 & 4 & 43 & 800 & 889.98 & 889.97 & 5.12 & 7.03 & $2.29 \mathrm{E}-09$ & 0.000 & 0.002 & 1 & 1200 & 0.284 & \\
\hline 242 & $05 / 04 / 17$ & $M-36$ & 300 & 4 & 43 & 850 & 889.97 & 889.96 & 9.12 & 10.33 & $1.29 \mathrm{E}-09$ & 0.002 & 0.002 & 1 & 1200 & 0.284 & \\
\hline 243 & $05 / 04 / 17$ & $M-36$ & 300 & 4 & 42 & 900 & 889.96 & 889.96 & 11.72 & 14.02 & 4.07E-10 & 0.002 & 0.002 & 1 & 1200 & 0.284 & \\
\hline 244 & $05 / 04 / 17$ & M-36 & 300 & 4 & 42 & 950 & 889.96 & 889.96 & 15.78 & 16.53 & 4.16E-10 & 0.002 & 0.003 & 1 & 1200 & 0.284 & \\
\hline 245 & $05 / 04 / 17$ & M-36 & 300 & 4 & 42 & 1000 & 889.96 & 889.95 & 17.87 & 19.17 & 1.20E-09 & 0.003 & 0.003 & 1 & 1200 & 0.284 & \\
\hline 246 & 05/08/17 & $M-37$ & 300 & 305 & 36 & 800 & 901.28 & 901.26 & 5.08 & 7.27 & $2.39 \mathrm{E}-09$ & 0.000 & 0.002 & 1 & 1200 & 0.131 & \\
\hline 247 & $05 / 08 / 17$ & $M-37$ & 300 & 341 & 37 & 850 & 901.26 & 901.25 & 8.32 & 10.52 & $2.38 \mathrm{E}-09$ & 0.002 & 0.004 & 1 & 1200 & 0.131 & \\
\hline 248 & 05/08/17 & $M-37$ & 300 & 333 & 34 & 900 & 901.25 & 901.23 & 11.73 & 13.60 & $2.64 \mathrm{E}-09$ & 0.004 & 0.006 & 1 & 1200 & 0.131 & \\
\hline 249 & 05/08/17 & $M-37$ & 300 & 356 & 34 & 950 & 901.23 & 901.17 & 14.67 & 16.87 & 8.41E-09 & 0.006 & 0.012 & 1 & 1200 & 0.131 & \\
\hline 250 & 05/08/17 & $M-37$ & 300 & 346 & 33 & 1000 & 901.17 & 900.87 & 17.83 & 19.97 & $4.31 \mathrm{E}-08$ & 0.012 & 0.045 & 1 & 1200 & 0.131 & \\
\hline 251 & 05/08/17 & $M-37$ & 300 & 348 & 35 & 1050 & 900.87 & 899.12 & 20.80 & 23.02 & $2.44 \mathrm{E}-07$ & 0.045 & 0.240 & 1 & 1200 & 0.131 & \\
\hline 252 & 05/08/17 & $M-37$ & 300 & 359 & 37 & 1100 & 899.12 & 893.42 & 23.73 & 25.73 & $8.80 \mathrm{E}-07$ & 0.240 & 0.872 & 1 & 1200 & 0.131 & \\
\hline
\end{tabular}


ORNL/TM-2018/1057

\begin{tabular}{|c|c|c|c|c|c|c|c|c|c|c|c|c|c|c|c|c|c|}
\hline \multirow{3}{*}{$\begin{array}{l}\text { Data } \\
\text { No. }\end{array}$} & \multirow{3}{*}{ Test date } & \multirow{3}{*}{$\begin{array}{c}\text { Spec. } \\
\text { ID }\end{array}$} & \multicolumn{2}{|c|}{$\mathrm{P}_{\mathrm{H} 2 \mathrm{O}}$} & \multirow{2}{*}{$\mathrm{P}_{\mathrm{H} 2}$} & \multirow{2}{*}{ Temp } & \multicolumn{2}{|c|}{ Weight } & \multicolumn{2}{|c|}{ Time in test } & \multirow[t]{2}{*}{ Rate } & \multicolumn{2}{|c|}{ Weight loss } & \multicolumn{3}{|c|}{ Preparation } & \multirow{2}{*}{ Notes } \\
\hline & & & target & actual & & & before & after & before & after & & before & after & time & temp & $\begin{array}{l}\text { wt. } \\
\text { loss }\end{array}$ & \\
\hline & & & $\mathrm{Pa}$ & $\mathrm{Pa}$ & $\mathrm{Pa}$ & ${ }^{\circ} \mathrm{C}$ & $\mathrm{mg}$ & $\mathrm{mg}$ & $\mathrm{h}$ & $\mathrm{h}$ & $\mathrm{s}^{-1}$ & $\%$ & $\%$ & $\mathrm{~h}$ & ${ }^{\circ} \mathrm{C}$ & $\mathrm{mg}$ & \\
\hline 253 & 05/10/17 & $M-38$ & 100 & 108 & 76 & 800 & 905.69 & 905.68 & 5.85 & 7.68 & $1.84 \mathrm{E}-09$ & 0.000 & 0.001 & 1 & 1200 & 0.034 & \\
\hline 254 & $05 / 10 / 17$ & $M-38$ & 100 & 108 & 77 & 850 & 905.68 & 905.67 & 8.60 & 10.90 & $1.20 \mathrm{E}-09$ & 0.001 & 0.002 & 1 & 1200 & 0.034 & \\
\hline 255 & $05 / 10 / 17$ & $M-38$ & 100 & 112 & 76 & 900 & 905.67 & 905.67 & 11.55 & 13.55 & $0.00 E+00$ & 0.002 & 0.002 & 1 & 1200 & 0.034 & R \\
\hline 256 & $05 / 10 / 17$ & $M-38$ & 100 & 114 & 76 & 950 & 905.67 & 905.67 & 14.62 & 16.78 & $5.68 \mathrm{E}-10$ & 0.002 & 0.003 & 1 & 1200 & 0.034 & $\mathrm{R}$ \\
\hline 257 & 05/10/17 & $M-38$ & 100 & 115 & 76 & 1000 & 905.67 & 905.65 & 17.80 & 19.95 & 3.00E-09 & 0.003 & 0.005 & 1 & 1200 & 0.034 & \\
\hline 258 & $05 / 10 / 17$ & M-38 & 100 & 111 & 76 & 1050 & 905.65 & 905.57 & 20.83 & 22.98 & $1.16 \mathrm{E}-08$ & 0.005 & 0.014 & 1 & 1200 & 0.034 & \\
\hline 259 & $05 / 10 / 17$ & $M-38$ & 100 & 110 & 76 & 1100 & 905.57 & 905.26 & 24.30 & 26.08 & $5.26 \mathrm{E}-08$ & 0.014 & 0.048 & 1 & 1200 & 0.034 & \\
\hline 260 & $05 / 11 / 17$ & M-39 & 50 & 61 & 25 & 800 & 895.08 & 895.06 & 5.12 & 7.53 & $2.58 \mathrm{E}-09$ & 0.000 & 0.002 & 1 & 1200 & 0.019 & \\
\hline 261 & 05/11/17 & M-39 & 50 & 39 & 24 & 850 & 895.06 & 895.05 & 9.70 & 10.68 & $2.53 \mathrm{E}-09$ & 0.002 & 0.003 & 1 & 1200 & 0.019 & \\
\hline 262 & $05 / 11 / 17$ & M-39 & 50 & 37 & 24 & 900 & 895.05 & 895.05 & 12.67 & 13.73 & 1.17E-09 & 0.003 & 0.004 & 1 & 1200 & 0.019 & \\
\hline 263 & $05 / 11 / 17$ & M-39 & 50 & 37 & 24 & 950 & 895.05 & 895.04 & 14.73 & 16.43 & $5.48 \mathrm{E}-10$ & 0.004 & 0.004 & 1 & 1200 & 0.019 & \\
\hline 264 & $05 / 11 / 17$ & M-39 & 50 & 37 & 25 & 1000 & 895.04 & 894.40 & 18.02 & 19.95 & $1.03 \mathrm{E}-07$ & 0.004 & 0.076 & 1 & 1200 & 0.019 & $\mathrm{R}$ \\
\hline 265 & 05/11/17 & M-39 & 50 & 37 & 24 & 1050 & 894.40 & 894.35 & 20.88 & 22.97 & 8.32E-09 & 0.076 & 0.082 & 1 & 1200 & 0.019 & \\
\hline 266 & $05 / 11 / 17$ & M-39 & 50 & 37 & 24 & 1100 & 894.35 & 894.20 & 23.97 & 25.83 & $2.49 \mathrm{E}-08$ & 0.082 & 0.098 & 1 & 1200 & 0.019 & \\
\hline 267 & $05 / 15 / 17$ & $M-40$ & 50 & 53 & 12 & 800 & 896.80 & 896.78 & 6.25 & 7.82 & 3.35E-09 & 0.000 & 0.002 & 1 & 1200 & 0.014 & \\
\hline 268 & $05 / 15 / 17$ & $M-40$ & 50 & 53 & 12 & 850 & 896.78 & 896.74 & 8.63 & 10.55 & $6.29 \mathrm{E}-09$ & 0.002 & 0.006 & 1 & 1200 & 0.014 & \\
\hline 269 & $05 / 15 / 17$ & $M-40$ & 50 & 53 & 12 & 900 & 896.74 & 896.73 & 11.70 & 13.68 & $1.56 \mathrm{E}-09$ & 0.006 & 0.007 & 1 & 1200 & 0.014 & \\
\hline 270 & $05 / 15 / 17$ & $M-40$ & 50 & 53 & 12 & 950 & 896.73 & 896.73 & 14.92 & 16.75 & $1.18 \mathrm{E}-09$ & 0.007 & 0.008 & 1 & 1200 & 0.014 & \\
\hline 271 & $05 / 15 / 17$ & $M-40$ & 50 & 53 & 12 & 1000 & 896.73 & 896.71 & 17.78 & 19.58 & 2.75E-09 & 0.008 & 0.010 & 1 & 1200 & 0.014 & \\
\hline 272 & $05 / 15 / 17$ & $M-40$ & 50 & 53 & 12 & 1050 & 896.71 & 896.63 & 20.88 & 22.83 & $1.27 \mathrm{E}-08$ & 0.010 & 0.019 & 1 & 1200 & 0.014 & \\
\hline 273 & $05 / 15 / 17$ & $M-40$ & 50 & 53 & 12 & 1100 & 896.63 & 896.30 & 23.92 & 26.08 & 4.76E-08 & 0.019 & 0.056 & 1 & 1200 & 0.014 & \\
\hline 274 & $05 / 16 / 17$ & $M-41$ & 20 & 22 & 25 & 800 & 894.65 & 894.62 & 5.13 & 7.68 & 3.53E-09 & 0.000 & 0.003 & 1 & 1200 & -0.003 & \\
\hline 275 & $05 / 16 / 17$ & $M-41$ & 20 & 22 & 25 & 850 & 894.62 & 894.61 & 8.37 & 10.45 & 2.39E-09 & 0.003 & 0.005 & 1 & 1200 & -0.003 & \\
\hline 276 & $05 / 16 / 17$ & M-41 & 20 & 33 & 25 & 900 & 894.61 & 894.59 & 11.68 & 13.62 & $1.92 \mathrm{E}-09$ & 0.005 & 0.006 & 1 & 1200 & -0.003 & \\
\hline 277 & $05 / 16 / 17$ & $M-41$ & 20 & 42 & 25 & 950 & 894.59 & 894.60 & 14.58 & 17.00 & $-2.57 \mathrm{E}-10$ & 0.006 & 0.006 & 1 & 1200 & -0.003 & $\mathrm{R}$ \\
\hline 278 & $05 / 16 / 17$ & $M-41$ & 20 & 47 & 25 & 1000 & 894.60 & 894.58 & 17.82 & 19.95 & 2.04E-09 & 0.006 & 0.008 & 1 & 1200 & -0.003 & \\
\hline
\end{tabular}


ORNL/TM-2018/1057

\begin{tabular}{|c|c|c|c|c|c|c|c|c|c|c|c|c|c|c|c|c|c|}
\hline \multirow{3}{*}{$\begin{array}{l}\text { Data } \\
\text { No. }\end{array}$} & \multirow{3}{*}{ Test date } & \multirow{3}{*}{$\begin{array}{c}\text { Spec. } \\
\text { ID }\end{array}$} & \multicolumn{2}{|c|}{$\mathrm{P}_{\mathrm{H} 2 \mathrm{O}}$} & \multirow{2}{*}{$\mathrm{P}_{\mathrm{H} 2}$} & \multirow{2}{*}{ Temp } & \multicolumn{2}{|c|}{ Weight } & \multicolumn{2}{|c|}{ Time in test } & \multirow[t]{2}{*}{ Rate } & \multicolumn{2}{|c|}{ Weight loss } & \multicolumn{3}{|c|}{ Preparation } & \multirow{2}{*}{ Notes } \\
\hline & & & target & actual & & & before & after & before & after & & before & after & time & temp & $\begin{array}{l}\text { wt. } \\
\text { loss }\end{array}$ & \\
\hline & & & $\mathrm{Pa}$ & $\mathrm{Pa}$ & $\mathrm{Pa}$ & ${ }^{\circ} \mathrm{C}$ & $\mathrm{mg}$ & $\mathrm{mg}$ & $\mathrm{h}$ & $\mathrm{h}$ & $\mathrm{s}^{-1}$ & $\%$ & $\%$ & $\mathrm{~h}$ & ${ }^{\circ} \mathrm{C}$ & $\mathrm{mg}$ & \\
\hline 279 & $05 / 16 / 17$ & $M-41$ & 20 & 52 & 25 & 1050 & 894.58 & 894.53 & 20.77 & 22.85 & 8.36E-09 & 0.008 & 0.014 & 1 & 1200 & -0.003 & \\
\hline 280 & $05 / 16 / 17$ & $M-41$ & 20 & 56 & 25 & 1100 & 894.53 & 894.30 & 23.95 & 26.02 & $3.36 \mathrm{E}-08$ & 0.014 & 0.039 & 1 & 1200 & -0.003 & \\
\hline 281 & $05 / 18 / 17$ & $M-42$ & 300 & 285 & 76 & 800 & 901.64 & 901.63 & 4.82 & 7.35 & 2.19E-09 & 0.000 & 0.002 & 1 & 1200 & -0.018 & \\
\hline 282 & $05 / 18 / 17$ & $M-42$ & 300 & 293 & 76 & 850 & 901.63 & 901.62 & 8.47 & 10.70 & $1.24 \mathrm{E}-09$ & 0.002 & 0.003 & 1 & 1200 & -0.018 & \\
\hline 283 & $05 / 18 / 17$ & $M-42$ & 300 & 297 & 71 & 900 & 901.62 & 901.62 & 11.58 & 13.77 & $1.41 \mathrm{E}-10$ & 0.003 & 0.003 & 1 & 1200 & -0.018 & \\
\hline 284 & $05 / 18 / 17$ & $M-42$ & 300 & 301 & 71 & 950 & 901.62 & 901.61 & 14.70 & 16.60 & $3.24 \mathrm{E}-10$ & 0.003 & 0.003 & 1 & 1200 & -0.018 & \\
\hline 285 & $05 / 18 / 17$ & $M-42$ & 300 & 327 & 73 & 1000 & 901.61 & 901.59 & 17.83 & 19.95 & 4.21E-09 & 0.003 & 0.007 & 1 & 1200 & -0.018 & \\
\hline 286 & $05 / 18 / 17$ & $M-42$ & 300 & 322 & 73 & 1050 & 901.59 & 901.28 & 20.75 & 23.12 & 4.03E-08 & 0.007 & 0.041 & 1 & 1200 & -0.018 & \\
\hline 287 & $05 / 18 / 17$ & $M-42$ & 300 & 326 & 74 & 1100 & 901.28 & 899.32 & 23.73 & 26.08 & 2.57E-07 & 0.041 & 0.258 & 1 & 1200 & -0.018 & \\
\hline
\end{tabular}

Notes: $\mathrm{R}=$ data rejected (negative of zero); UR - unreliable data 